2011s-34

\title{
The Determination of Optimal Fines in Cartel Cases The Myth of Underdeterrence
}

\author{
Marie-Laure Allain, Marcel Boyer,
} Rachidi Kotchoni, Jean-Pierre Ponssard

\section{Série Scientifique \\ Scientific Series}

\author{
Montréal \\ Mars 2011 \\ Mise à jour : 8 septembre 2011 \\ Update: Septembre 8, 2011
}

(C) 2011 Marie-Laure Allain, Marcel Boyer, Rachidi Kotchoni, Jean-Pierre Ponssard. Tous droits réservés. All rights reserved. Reproduction partielle permise avec citation du document source, incluant la notice (C).

Short sections may be quoted without explicit permission, if full credit, including (C) notice, is given to the source.
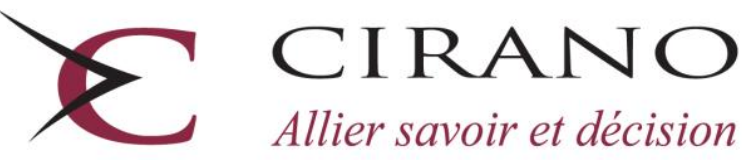

Allier savoir et décision

Centre interuniversitaire de recherche en analyse des organisations 


\section{CIRANO}

Le CIRANO est un organisme sans but lucratif constitué en vertu de la Loi des compagnies du Québec. Le financement de son infrastructure et de ses activités de recherche provient des cotisations de ses organisations-membres, d'une subvention d'infrastructure du Ministère du Développement économique et régional et de la Recherche, de même que des subventions et mandats obtenus par ses équipes de recherche.

CIRANO is a private non-profit organization incorporated under the Québec Companies Act. Its infrastructure and research activities are funded through fees paid by member organizations, an infrastructure grant from the Ministère du Développement économique et régional et de la Recherche, and grants and research mandates obtained by its research teams.

\section{Les partenaires du CIRANO}

Partenaire majeur

Ministère du Développement économique, de l'Innovation et de l'Exportation

\section{Partenaires corporatifs}

Banque de développement du Canada

Banque du Canada

Banque Laurentienne du Canada

Banque Nationale du Canada

Banque Royale du Canada

Banque Scotia

Bell Canada

BMO Groupe financier

Caisse de dépôt et placement du Québec

Fédération des caisses Desjardins du Québec

Financière Sun Life, Québec

Gaz Métro

Hydro-Québec

Industrie Canada

Investissements PSP

Ministère des Finances du Québec

Power Corporation du Canada

Raymond Chabot Grant Thornton

Rio Tinto

State Street Global Advisors

Transat A.T.

Ville de Montréal

\section{Partenaires universitaires}

École Polytechnique de Montréal

HEC Montréal

McGill University

Université Concordia

Université de Montréal

Université de Sherbrooke

Université du Québec

Université du Québec à Montréal

Université Laval

Le CIRANO collabore avec de nombreux centres et chaires de recherche universitaires dont on peut consulter la liste sur son site web.

Les cahiers de la série scientifique (CS) visent à rendre accessibles des résultats de recherche effectuée au CIRANO afin de susciter échanges et commentaires. Ces cahiers sont écrits dans le style des publications scientifiques. Les idées et les opinions émises sont sous l'unique responsabilité des auteurs et ne représentent pas nécessairement les positions du CIRANO ou de ses partenaires.

This paper presents research carried out at CIRANO and aims at encouraging discussion and comment. The observations and viewpoints expressed are the sole responsibility of the authors. They do not necessarily represent positions of CIRANO or its partners. 


\title{
The Determination of Optimal Fines in Cartel Cases The Myth of Underdeterrence*
}

\author{
Marie-Laure Allain ${ }^{\dagger}$, Marcel Boyer, \\ Rachidi Kotchoni $^{\S}$, Jean-Pierre Ponssard ${ }^{* *}$
}

\begin{abstract}
Résumé / Abstract
La détermination d'amendes optimales pour dissuader la formation ou la poursuite des cartels est au cœur des politiques de concurrence. Nous définissons un cadre stratégique pour caractériser le caractère restitutif et dissuasif des amendes dans des contextes statique et dynamique : la stabilité d'un cartel dépend de sa capacité à prévenir les déviations dont la profitabilité est fonction des amendes imposées lorsque le cartel est découvert. Nous montrons que la prise en compte appropriée de la dynamique de la concurrence a un impact majeur sur la détermination des amendes dissuasives optimales : nos résultats suggèrent qu'une nette majorité des amendes infligées par la Commission Européenne ces dernières années rencontrent l'objectif de dissuasion.
\end{abstract}

Mots clés : Amendes optimales, cartels.

The determination of optimal fines to deter the formation or continuation of cartels is a major objective of competition policy. We provide an analysis of static and dynamic frameworks to characterize the restitution and deterrence properties of fines: cartel stability depends on their ability to prevent deviation by firms, while the benefit of a deviation depends on the fines to be imposed in case of detection by the antitrust authority. We show that the proper consideration of the dynamics of competition has a major impact on the determination of optimal dissuasive fines: our results suggest that a clear majority of fines imposed by the European Commission in recent years meet the deterrence objective.

Keywords: Optimal fines, cartels.

\footnotetext{
* We are grateful to Paolo Buccirossi (LEAR), Joe Harrington (Johns Hopkins University), Wouter Wils (European Commission), François Brunet (Cleary Gottlieb Steen \& Hamilton LLP, Paris) as well as to participants at presentations before the International Chamber of Commerce in Paris, London and New York, the US Council for International Business in New York, and the Autorité de la Concurrence in Paris for their comments. Needless to say, we remain solely responsible for the content of this paper.

${ }^{\dagger}$ École Polytechnique, Paris.

${ }^{\sharp}$ Bell Canada Emeritus Professor of Industrial Economics, Université de Montréal, Research Associate, Department of Economics, École Polytechnique de Paris, University Affiliate, Analysis Group, Inc., Fellow of CIRANO, CIREQ and C.D. Howe Institute.

${ }^{\S}$ Université Laval.

** École Polytechnique, Paris.
} 


\section{Introduction}

We are concerned in this paper with the determination of optimal fines to deter the formation of cartels and, if they are formed, to favour their collapse through firms' deviation from cartel agreements. Antitrust authorities rely mainly on financial penalties to enforce laws against cartels. ${ }^{1}$ The economic theory of crime has shown that fines may fail to be deterrent or to be restitutive, thus failing to reduce the social harm caused by cartels. Yet excessive fines may also induce a social cost, by raising too much the intensity of incentives to find and prosecute cartels, thereby increasing the cost of antitrust resources and raising the cost and probability of type I errors, that is, finding guilty innocent parties. ${ }^{2}$ We discuss the optimal level of fines in cartel cases in line with the objectives of antitrust policy, and compare this level to the actual level of fines imposed by antitrust authorities. Our results suggest that a clear majority of recent fines imposed by the European Commission satisfies the dissuasive objective.

A cartel is a group of independent firms which collectively agree to coordinate their supply, pricing or other policies in order to make larger profits than they would in a market where "natural competition" prevails. Firms typically collude only if the price increase they can implement (the "overcharge") generates a net incremental payoff (the "excess profit") that is more than sufficient to cover the cartel costs. Cartels pursue their goals at the expense of customers' interests and well-being, and as such, are harmful for society. Most advanced economies consider therefore cartels as illegal.

The United States Sentencing Guidelines (USSG) recommend the imposition of a base fine of $10 \%$ of the affected volume of commerce to a firm convicted of cartel collusion plus another $10 \%$ for the harms inflicted upon consumers. As this amount may undergo some adjustments for aggravating and mitigating factors, the total fine typically ranges from $15 \%$ to $80 \%$ of affected sales. The amount of fines imposed to convicted cartels has dramatically increased in recent years, from 889 millions $\$$ over the period 2000-2004 to 3.4 billion \$ over the period 2005-2009. ${ }^{3}$

In the European Union, the amount of the fine takes into account the severity of the damages inflicted upon consumers as well as some aggravating and mitigating factors. However, the total fine must not exceed $10 \%$ of the total annual turnover of an undertaking, which may be much larger than

\footnotetext{
${ }^{1}$ A number of countries have adopted criminal sanctions against individuals who engaged in hardcore cartels (for example, the US, Canada and Japan), but only a few countries within Europe (principally Austria, Norway, Ireland, the United Kingdom and, in relation to bid-rigging, Germany).

${ }^{2}$ The modeling of games involving predator and prey or police and criminals must rely on mixed strategies in order to avoid bang bang phenomena and carry forward the idea that it is illusive and too costly to eradicate all crimes in society. For such an approach see Boyer, Lewis and Liu (2000). Contrary to opinions often heard, the optimal level of crime in society is not zero: under an optimally designed antitrust policy (including both financial sanctions on corporations and individuals as well as personal sanctions such as debarment and prison terms for individuals), cartels will continue to be formed and maintained not because of firm myopia or error but because some of those cartels remain profitable. See Ginsburg and Wright (2010) and Harrington (2010) on these issues.

${ }^{3}$ U.S. Department of Justice, Antitrust Division.
} 
the affected sales. The amount of fines imposed to convicted cartels has also dramatically increased in recent years, from 293 million $€$ over the period 1995-1999 to 3.5 billion $€$ over the period 2000-2004 to 9.8 billion $€$ over the period $2005-2009$. $^{4}$

It may be useful to recall the definition of a restitution fine as opposed to a dissuasive fine. The restitution fine is the fine that permits to seize back the illegal profits realized by a particular cartel. The restitution fines collected from all cartels may not be restitutive at the aggregate level because some cartels will disappear before being discovered or may remain undiscovered forever. The proper dissuasive fine level is that level which makes unprofitable the formation of a cartel or unsustainable its continuation. Firms are deterred from participating in cartels if the expected net incremental profit from participating in the cartel is negative. Hence the viewpoint taken in characterizing dissuasive fines is that of the cartel itself, more precisely that of the firms in the cartels. Each individual firm must determine if participating in the cartel will generate a net increase in profits sufficient to cover the expected fine, when compared with the no cartel or but-for situation. It must also decide, when the cartel has been in effect for some time, if continuing to abide by the cartel agreement is more profitable than deviating from it.

One of the driving factor behind the increases in fines is the desire to make the fines dissuasive and not only restitutive. Indeed, the 2006 Guidelines indicate very clearly the importance of the dissuation objective in setting the fines: ${ }^{5}$

Point 4. The Commission's power to impose fines ... is one of the means ... to carry out the task of supervision entrusted to it by the Treaty. That task not only includes the duty to investigate and sanction individual infringements, but it also encompasses the duty to pursue a general policy designed to apply, in competition matters, the principles laid down by the Treaty and to steer the conduct of undertakings in the light of those principles. For this purpose, the Commission must ensure that its action has the necessary deterrent effect ... not only in order to sanction the undertakings concerned (specific deterrence) but also in order to deter other undertakings from engaging in, or continuing, behaviour that is contrary to Articles 81 and 82 of the EC Treaty (general deterrence) [italics added]. ${ }^{6}$

The economic theory of dissuasion of criminal activities relies on two main approaches, which both proceed from the theory of deterrence of criminal activities developed by Becker (1968) and

\footnotetext{
${ }^{4}$ European Commission, Directorate General of Competition. For a statistical review of the evolution of fines over the 1998-2006 period, see Veljanovski (2010).

${ }^{5}$ European Commission, "Guidelines on the method of setting fines imposed pursuant to Article 23(2)(a) of Regulation No 1/2003 (2006/C 210/02)". See also the Communiqué issued by the French Autorité de la Concurrence launching the public consultation on Antitrust fines (Communiqué of January 17 2011, in particular paragraphs 41 and 42).

${ }^{6}$ The Guidelines stress the dissuasive property of fines in many other Points: 7, 25, 30, 31, 37 among others.
} 
Landes (1983). One approach puts an emphasis on the restitution of criminal gains and the proper compensation of victims. The golden rule of this approach asserts that the fine should be equal to the harm that criminal activities have caused to society (including the costs incurred for finding and prosecuting criminals) divided by the probability of detection and conviction. To make sure the total restitution fines collected is in line with the total value of the harm caused, one needs to use a long term probability of detection concept. However, basing fines on a case-by-case estimation of damages would be costly. ${ }^{7}$ Implicit in the Becker-Landes paradigm is the belief that not all crimes can or should be deterred.

In contrast, the second approach directly addresses the dissuasion of criminal activities: punishment should be such that criminal activities are unprofitable. This optimal deterrence approach relies therefore on the idea that, for a given probability of detection, the fine should be high enough to wipe out any expected profit from the infringement. The first approach focuses on the recuperation of illicit profits and the compensation of harmed victims while the second one considers the impact of penalties on the profitability of engaging in illicit activities.

Surprisingly, the large economic literature on cartels $^{8}$ has not devoted much space to the assessment of the effectiveness of current antitrust practices. Most of the applied literature reviewed in Connor and Bolotova (2006) deals with the estimation of cartel overcharges, leaving open the actual determination of the optimal fines. However, after collecting and examining a larger data set, Connor (2010) concludes that "...penalty guidelines aimed at optimally deterring cartels ought to be increased". Combe and Monnier (2010) consider 64 recently prosecuted cartel cases in the EU and contribute to filling the gap between evaluating cartel overcharges giving rise to illicit gains and defining and computing "optimal" restitutive and dissuasive fine benchmarks, in part directly from the court evidence and in part based on Connor's reviews of cartel overcharges. They use the latter benchmarks to gauge the actual fines inflicted to the 64 cartels they considered. From their theoretical analysis and empirical estimates, they concluded that "fines imposed against cartels by the European Commission are overall sub optimal".

About two decades before, Cohen and Scheffman (1989) expressed a different viewpoint. They were among the first to overtly criticize the US antitrust policy (more precisely the 1989 Guidelines) at a time where the level of fines was quite modest compared to recent years. They argued that the estimation of damages by the antitrust authorities was not economically grounded: the antitrust authorities did not properly take into account the reaction of customers to a price increase (through the price elasticity of demand) and thus "the Justice Department's assertion that price-fixing conspiracies would typically result in a mark-up over competitive level of ten percent [...] is not supported by the

\footnotetext{
${ }^{7}$ See for instance OXERA (2009).

${ }^{8}$ See Motta (2004).
} 
available evidence. [...] This conclusion has important implications because of the potential inefficiencies that may arise from overdeterrence" (page 349). Recently, Connor (2011) aknowledges that, following the 2006 Guidelines, increases in fine levels imposed on cartels by the European Commission make recent fines confiscatory in many cases: "For the first time in antitrust history, I believe we are observing fines that regularly disgorge the monopoly profits accumulated by cartelists" and "The new Guidelines produced hard-core cartel fines that were more than six times as severe as comparable fines imposed under the 1998 Guidelines."

Boyer and Kotchoni (2011), using an updated Connor database, note that the Connor data are overcharge estimates rather than true observations and therefore subject to model error, estimation error and publication bias. Once controlling for the asymmetry (skewness), heterogeneity, publication bias, as well as the presence of a small number of influential observations (outliers) in the data, they conduct a meta-analysis of cartel overcharge estimates in the spirit of Connor and Bolotova (2006). They find that the mean bias-corrected overcharge estimate for cartels with raw positive overcharge estimates under $50 \%$ (the bulk of cartel cases) is $13.6 \%$ with a median of $13.6 \%$, while the mean for all cartels of all types is $17.5 \%$ with a median of $14.1 \%$. They argue that median values are in this case more informative and reliable as representative of cartel overcharge and that those values must be considered as upper bounds (given their conservative assumptions).

In this paper, we review the process to design dissuasive fines from cartel overcharges. We highlight the role of a crucial modeling factor, which is swept under the rug in many contributions, namely the dynamic dimension in the strategic behavior of firms (or cartels). Indeed, the issue of cartel stability and the role of fine in deterring the formation of cartels must be analyzed in a dynamic framework. We will show that the proper and explicit consideration of such a dynamic framework, together with the determination of representative overcharge estimates properly corrected for model errors, estimation errors and publication bias, have a major impact on the determination of optimal dissuasive fines: the restitutive and dissuasive benchmarks measured by Combe and Monnier (2010) should be reduced by factors no smaller than two and ten respectively. This suggests that, considering the sample of cartels studied by Combe and Monnier, approximately two thirds of the fines imposed are above the properly defined restitutive benchmark and at least half of them are above the properly defined dissuasive benchmark.

The rest of this paper is organized as follows. In Section 2, we present the general methodology to define the economic benchmarks that we use to assess the deterrent character of actual fines. This methodology is then formalized in two contexts: in a static framework (Section 3) and in a dynamic framework (Section 4). We revisit the Combe and Monnier results in Section 5. Section 6 concludes, putting the choice of fines as part of a more general set of policy intruments. 


\section{Economic Benchmarks for Cartel Fines}

The general methodology to obtain economic benchmarks for the determination of restitutive and dissuasive fines in cartel cases is sketched in Table 1.

Table 1: Methodology to determine economic benchmarks for cartel fines

\begin{tabular}{|c|c|c|}
\hline Step & & To be estimated \\
\hline 1 & Overcharge & $\begin{array}{c}\text { Price increase } \\
\text { versus but-for price }\end{array}$ \\
\hline 2 & Excess profit & $\begin{array}{c}\text { Competitive mark-up } \\
\text { Price elasticity }\end{array}$ \\
\hline $3-1$ & Restitution fine & Cartel duration \\
\hline $3-2$ & Dissuasive fine & Probability of detection \\
\hline
\end{tabular}

Step 1 refers to the price overcharge due to cartelization. It is defined as the percent increase over the price that would prevail in the absence of a cartel, known as the "but-for price". This price is usually assessed through various methods such as: before and after methods, yardstick methods, cost based methods, econometric models. Step 2 aims to estimate the excess (or illicit) profit realized by the cartel over and above the natural competition level. Here, one needs to introduce notions such as the competitive mark-up, i.e. the competitive price over the marginal cost, and the demand elasticity. Step 3-1 aims to estimate the restitution fine. This may be done by first assessing the (average) annual excess or illegal profit of the cartel and multiplying it by the duration of the cartel. The dissuasive fine is obtained at step 3-2 by combining excess profits and the probability of detection in ways we discuss below. Clearly, there is disagreement among analysts regarding the best or better way to model and measure excess profits and the probability of detection and conviction. As mentioned in the introduction, antitrust authorities are currently aiming more to meet a dissuasion objective than a restitution one.

To formalize the restitutive and dissuasive fine benchmarks in an economic framework, we must embed the analysis in a model of competition. The competition model may be static or dynamic. Static models of competition are simpler and are often used as short-cuts, but they may be misleading if the relevant stakes reside in the dynamic nature of the strategic interaction between the players or firms. Dynamic models of competition are more realistic, but they are also more complex and therefore, more subject to ad hoc assumptions. Moreover, dynamic models tend to be plagued by a multiplicity of equilibria. 
Whatever the economic framework used, it is important to remember that industry characteristics play a significant role in determining the economic model of competition, and these characteristics must be accounted for in empirical works. If empirical observations suggest that a Bertrand-type competition (i.e. price competition with a homogenous good) prevails in an industry, then the competitive equilibrium price (which becomes the but-for price if a cartel is formed) is close to the marginal cost of production. If evidence suggests that a Cournot-type competition (i.e. quantity competition with a homogenous product) or a monopolistic competition (i.e. price or quantity competition with differentiated products) prevails, then the equilibrium price(s) may be significantly higher than marginal cost(s) of production, in particular if the market is concentrated.

The industry concentration may be due to structural exogenous factors such as scarcity of some inputs, location, first-movers advantage, etc., which may explain or justify positive economic profits (but of course the excess profits due to cartelization are not). The concentration may also be due to endogenous factors such as large advertising budgets, R\&D expenses, and significant fixed investments, all factors which give rise to sunk costs that can only be indirectly recovered and should be taken into account in the assessment of average costs.

In some circumstances, it may be appropriate to go one step further in complexity in designing an economic model of competition compatible with the presence of risk and uncertainty as well as dynamic factors such as business cycles, investment decisions, set up costs, capacity constraints, etc., which may have a strong influence in the evolving market structure.

In dynamic models, special attention should be given to situations in which, due to the characteristics of the industry, the competition between firms may give rise to non cooperative long term equilibria that mimic collusive outcomes (the so-called "tacit collusion equilibria"). According to Ivaldi et al. (2003), the likelihood of observing a non cooperative equilibrium that mimics a collusive outcome $^{9}$ is higher when there are fewer competitors, demand is less volatile, innovation is lower, costs and/or production capacities are similar across firms, entry barriers are more important, firms interact more frequently, the market is more transparent (knowledge of prices and output), and demand growth is more important.

For clarity of exposition, we will first formalize the economic benchmarks using the much simpler static framework. We will then show how these benchmarks should be reconsidered in a more realistic dynamic perspective.

\footnotetext{
${ }^{9}$ See also Bernheim and Whinston (1990), Rothschild, (1999), and Verboven (1997).
} 


\section{Defining the Benchmarks in a Static Framework}

The market power of a firm may be defined as its ability to influence the market outcome to its own advantage. More often than not, firms' market power translates into the difference between actual prices and the prices that would prevail in pure and perfect competition. Indeed, in pure and perfect competition, both the sellers and buyers are price-takers. No player believes that his or her actions can influence the equilibrium price. At the other extreme, a monopoly (a single seller or a single buyer) grants a firm with the highest possible market power. Between these two extremes, there are various forms and levels of competition that may grant firms with little market power (Bertrand) or mild to severe forms of market power (Cournot, monopolistic competition). In assessing the illegal profit accruing to cartels, a major challenge resides not only in the determination of the market power that the firms would exert absent the cartel, but also in the evaluation of the impact of price changes on demand.

\subsection{The standard approach}

A standard way to define the benchmarks in a static framework is summarized in Sidebar 1 taken from Buccirossi and Spagnolo (2007). ${ }^{10}$ It shows that the excess profit depends on three main parameters, namely the price increase due to the cartel, the price elasticity of demand, and the competitive mark-up, and it indicates how the restitutive and dissuasive benchmarks can be characterized. $^{11}$

The following graph illustrates the basic intuitions behind the determination of the excess profit. The profit of the firm in a competitive market is the area consisting of $\mathrm{B}+\mathrm{C}=(p-c) q$. If a cartel is formed, the profit becomes $\mathrm{A}+\mathrm{B}=\left(p^{m}-c\right) q^{m}$. The excess profit is thus A-C.

\footnotetext{
${ }^{10}$ See also Werden and Simon (1987), Gallo et al. (1994) among others, and more recently Combe and Monnier (2010).

${ }^{11}$ One must be careful in using such a tool as the parameters $\varepsilon$ (price elasticity of demand), $m$ (competitive markup and $k$ (cartel price overcharge) are not independent: both $m$ and $k$ depend on $\varepsilon$ (the price elasticity of demand is an important determinant of market power in a market), and a larger $m$ will in general imply a lower $k$ (if the competitive mark-up is already high, the cartel overcharge will tend to be lower).
} 


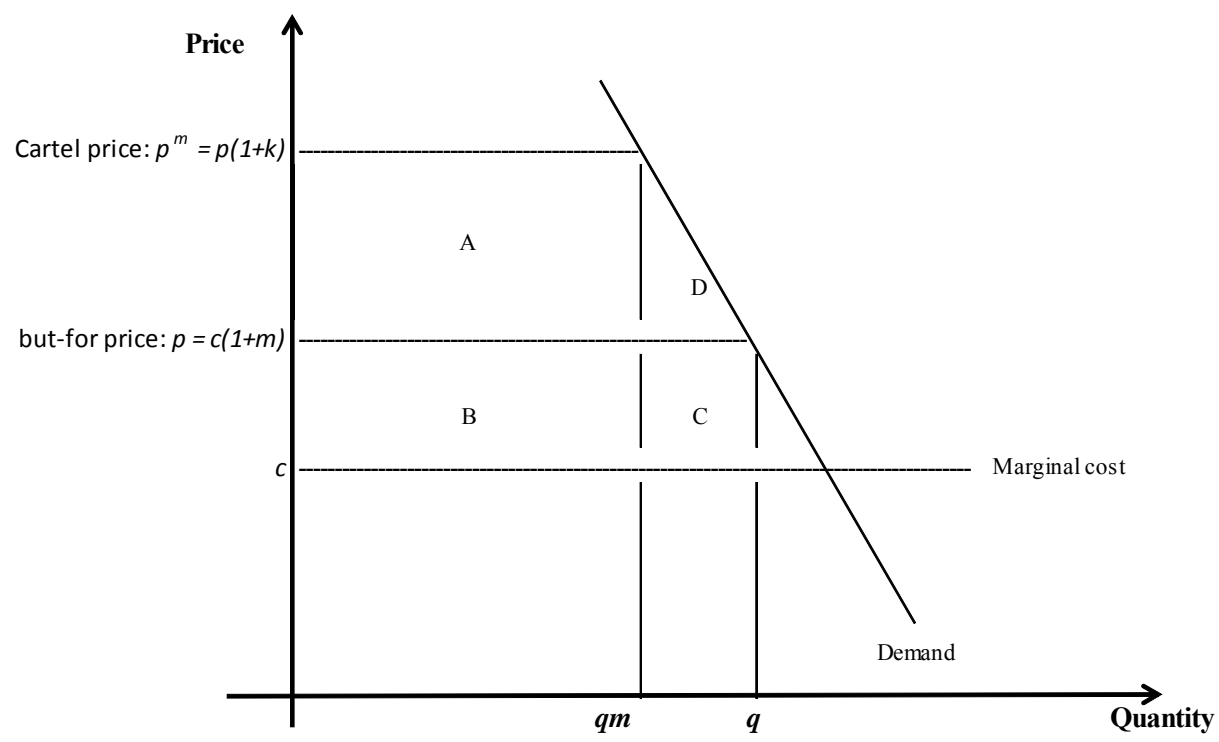

The game tree depicted in Figure 1 shows the different decisions and possibilities facing firms. Either they do not form a cartel (nc), in which case they enjoy a profit level of $\pi$ (the but-for profit), or they do form a cartel (c) in which case they face two possibilities, namely not being caught and enjoying profit level $\pi^{\mathrm{m}}$, a possibility whose probability of occurrence is $(1-\alpha)$, or the possibility of being detected and convicted and suffering a fine of fS and thus a drop in profit to $\pi^{\mathrm{m}}$ - $\mathrm{fS}$, a possibility whose probability of occurrence is $\alpha$.

Figure 1: The decision tree for cartel formation in a static framework

$$
1-\alpha \quad \pi^{m}
$$

C $\alpha$

$$
\pi^{\mathrm{m}}-\mathrm{fS}
$$




\section{Sidebar1: Illicit profits, restitution fines and dissuasive fines as a \% of sales}

The method presented below is referred to by Buccirossi and Spagnolo (2007) as the traditional approach to compute the restitutive and dissuasive fine benchmarks. It uses the following variables:

$p$ is the competitive price (the "but-for" price);

$c$ is the marginal cost (assumed constant);

$m$ is the competitive mark-up $m=(p-c) / c$

$k$ is the percentage price increase due to the cartel: the cartel price is $p^{m}=p(1+k)$

$q$ is the quantity demanded at the competitive price;

$\varepsilon$ is the absolute value of the demand elasticity at the competitive price;

$q^{m}$ is the quantity demanded at the cartel price, $; q^{m}=q(1-\varepsilon k)$

$\alpha$ is the probability of detection of the cartel;

$f$ is the fine expressed as a fraction of the firms' revenue in the affected market.

Absent the cartel, each firm's profit is $\pi=q(p-c)=q \mathrm{~cm}$

In the cartel, each colluding firm's profit is

$$
\pi^{m}=q^{m}\left(p^{m}-c\right)=q c(1-\varepsilon k)(m+k+m k)
$$

Therefore a colluding firm increases its profits by:

$$
\Delta \pi=\pi^{m}-\pi=q k c((1+m)(1-\varepsilon k)-\varepsilon m)
$$

Sales (noted $S$ ) in the market at the colluding price are:

$$
S=q^{m} p^{m}=q c(1+m)(1+k)(1-\varepsilon k)
$$

The excess profit as a percentage of sales is

$$
\Delta \pi / S=k[(1+m)(1-\varepsilon k)-\varepsilon m] /(1+m)(1+k)(1-\varepsilon k)]
$$

Observe that if $m$ or $\varepsilon$ are zero this expression reduces to $k /(k+1)$.

The restitution fine as a percentage of cartel sales, denoted $F$, is directly

$$
F=\Delta \pi / S
$$

Denote by $\alpha$ that the probability of detection and $b y f$ the dissuasive fine as a percentage of cartel sales. If the industry cartelizes each member of the cartel will get its cartel profit $\pi^{m}$. The cartel will be detected with probability $\alpha$. If the industry does not cartelize each firm gets its competitive profit $\pi$. Figure 2 depicts the corresponding decision tree. The fine is dissuasive if and only if

$$
\pi^{m}-\alpha f S \leq \pi \text { that is if and only if } f \geq(\Delta \pi / S) / \alpha .
$$

Clearly, a larger probability of detection (through a leniency program, for instance) would justify a lower dissuasive fine. 
Note that in this static framework, the excess profit and the probability of detection are defined for the same cartel duration, whatever that duration is. Suppose that the cartel duration is known to be $n$ years and that the probability of detection per year is constant and equal to $\alpha_{l}$, the overall n-year probability of detection is equal to $\alpha_{n}=1-\left(1-\alpha_{1}\right)^{n} \cdot{ }^{12}$ With $\Delta \pi / S$ being the cartel annual excess profit as a percentage of affected sales, the n-year benchmark for the dissuasive fine is given by the following, henceforth the "overall n-year static dissuasive fine":

$$
f=n(\Delta \pi / S) / \alpha_{n}
$$

As pointed out by Buccirossi and Spagnolo (2007), this static approach is not satisfactory in all respects. ${ }^{13}$ They suggested that a better definition of the optimal fine must account for the fact that the stability of a cartel depends on the incentives of each member to abide by the cartel agreement. Indeed, cartels are subject to defection by any member who wishes either to benefit by cutting the cartel price, or to benefit from a leniency program, or both. The presence of a leniency program that ensures that the deviant firm is not fined increases the probability of detection and conviction and hence, cartels can be deterred with a (significantly) lower fine than the optimal fine prescribed by the previous static approach. ${ }^{14}$ In Section 4 , we formalize these ideas in the context of a dynamic strategic game.

The procedure presented in Sidebar 1 is simple to understand. However, besides the (often neglected) interdependency of the parameters discussed above, ${ }^{15}$ its application to derive numerical benchmarks requires that the various parameters be estimated. In light of this economic model, two examples of pitfalls to avoid in assessing the overcharge (or parameter $k$ in sidebar 1) are discussed next. The first one concerns yardstick methods (and also applies to before and after methods), and the second one refers to the use of the Lerner index as an indicator of the market power and price overcharge of the cartel.

\footnotetext{
${ }^{12}$ The period over which $\Delta \pi$ and $\alpha$ are defined is usually one year, but one could consider alternative periods such as six months, 18 months, and $\mathrm{n}$ years. The values of $\Delta \pi$ and $\alpha$ must of course be adjusted accordingly. Suppose that the values of $\Delta \pi$ and $\alpha$ have been defined for a period of one year. The adjustment of $\Delta \pi$ for the alternative periods would simply be $1 / 2 \Delta \pi, 1.5 \Delta \pi$, and $\mathrm{n} \Delta \pi$. For $\alpha$, the adjustment is a bit more complex. Consider a period of three years. Since $\alpha$ is defined as the probability of detection over one year, the corresponding probability of detection over three years must be: $\alpha+\alpha(1-\alpha)+\alpha(1-\alpha)^{2}=1-(1-\alpha)^{3}$. For a n-year cartel, the nyear probability of detection is $1-(1-\alpha)^{\mathrm{n}}$.

${ }_{13}$ Surprisingly, relatively few authors have analyzed this question in a dynamic framework. In a static framework, Souam (2001) compares the efficiency of two different regimes of fines against cartels when antitrust authorities have limited resource: the first one involves fines based on the industry's total sales, while the second involves fines based on damages incurred by consumers. Souam shows that the second regime has better deterrence properties if and only if market conditions make collusion very likely.

${ }^{14}$ Besides noting that leniency programs would allow a reduction in dissuasive fines, Buccirossi and Spagnolo claim that " ... considering our initial simulation [an overcharge of $10 \%$ ], a cartel with five members in a market whose competitive mark-up is 0 could be deterred by imposing a fine on non-reporting firms equal to less than $2 \%$ of the firms' affected commerce over the entire duration of the cartel and paying a reward to the whistleblower equal to the collected fine."

${ }^{15}$ See footnote 11.
} 


\subsection{Potential pitfalls in using yardstick methods}

Yardstick methods are often used to determine but-for environments. Here we stress the importance of using that type of methods only when the market conditions are similar in order to avoid errors in the estimation of damages. In particular, we show that if an equilibrium price of a comparable market with no cartel is used as a but-for price estimate (the yardstick), then the differences in demand price elasticity between the two markets must be known for the yardstick methods to be effective. If the price elasticity of demand is higher in the yardstick market, the equilibrium price will be lower than the but-for price that would have prevailed in the market. Hence, there would be an overestimation of damages. ${ }^{16}$

Consider for instance a static and symmetric Cournot duopoly framework. ${ }^{17}$ The price elasticity of demand $\varepsilon$ and the Cournot equilibrium price $P_{C}$ are related:

$$
P_{C}=\left[\frac{\varepsilon}{\varepsilon-0.5}\right] M C,
$$

where $M C$ is the marginal cost (supposed constant).. For example, assume that good A is sold in regions 1 and 2. Symmetric Cournot duopolies operate in both markets, but the distance between the two markets is such that region 1 firms cannot compete with region 2 firms. Moreover, suppose that in region 2 a non-perfect substitute for good $\mathrm{A}$ is available which causes the price elasticity of demand to be higher in region 2 than in region 1. Suppose also that marginal costs are constant and identical in both regions $\left(M C_{1}=M C_{2}\right)$ and that, for regions 1 and 2, the price elasticity of demand is constant and equal to 1 and 1.50 respectively. According to (1), we have the following Cournot equilibrium prices ( $P_{C}^{1}$ in region 1 and $P_{C}^{2}$ in region 2): $P_{C}^{1}=2 M C_{1}$ and $P_{C}^{2}=1.5 M C_{2}$.

Suppose now that the firms in region 1 are accused of a price fixing collusion which was active during a given period, and that during the same period, region 2 has remained competitive à la Cournot. To compute the damages caused by the cartel, a straightforward and intuitive candidate "but-for" price

\footnotetext{
${ }^{16}$ The price elasticity of demand is the measure of the sensitivity of the quantity demanded relative to a change in price. For example, a $1 \%$ price increase followed by a $2 \%$ drop in quantity demanded implies a price elasticity of demand equal to (negative) 2. A high price elasticity of demand suggests that consumers are easily able to find substitutes for the good of interest whose price has increased. Hence, higher elasticity of demand implies lower market power and lower prices in markets characterized by both oligopoly and monopoly. Therefore, the mark-up over marginal costs that the monopolist and firms in the Cournot duopoly can exert is decreasing with the price elasticity of demand (e.g., the higher the elasticity, the lower the mark-up).

${ }^{17}$ See for instance Borenstein, Bushnell and Knittel (1997).
} 
could be the price observed in region 2 during the cartel period. However, the Cournot equilibrium price in region 1 should always be higher than in region 2 . If we take the ratio of $P_{C}^{1}$ and $P_{C}^{2}$, we obtain 1.33 and consequently, using the price in region 2 as a "but-for" price estimate would lead to an improper assessment of damages, in this case an overestimation of damages. ${ }^{18}$

Despite the fact that the static Cournot duopoly framework is a crude simplification of reality, it still gives interesting insights on the features to consider when assessing the validity of a "but-for" price. Depending on the chosen "but-for" price estimation methodology, the above type of analysis can give an indication of the plausibility of the difference between the observed cartel price and the "but-for" price. This type of analysis also gives an indication as to the features to consider when assessing the suitability of the data used to come up with a counterfactual.

Industry characteristics play a significant role in determining the theoretical but-for-price, and these characteristics should be accounted for in any serious empirical assessment. To put it differently any attempt to use one of the pure empirical methods to estimate the but-for-price should incorporate an explicit economic theory of competition.

\subsection{Potential pitfalls in using the Lerner index as a short-cut of the cartel market power}

Sidebar 1 describes a methodology to derive the excess profit from the cartel overcharge, the competitive mark-up and the demand elasticity. Recall that if the competitive mark-up is assumed to be zero, then the excess profit as a percentage of sales can be directly taken as $k /(k+1)$, where $k$ is the cartel overcharge. ${ }^{19}$ In that case, $k /(k+1)=\left(p^{m}-c\right) / p^{m}$ which is the well known Lerner index, the cartel price over the marginal cost divided by the cartel price. In the special case in which the but-for price is taken as the marginal cost $(m=0)$, the Lerner index corresponds exactly to the excess profit as a percentage of cartel sales. This provides a handy but slippery short-cut to define benchmarks.

In Connor (2006), the overcharges displayed in Table 12, 12A, 12B are inferred from Lerner indices previously estimated by Bernheim (2002). ${ }^{20}$ The average overcharge inferred by Connor is above $40 \%$, a high percentage potentially attribuable to the propensity of the calculation method used to overstate the true excess profit. In the following citation, Connor (2007) seems to acknowledge that the but-for price should reflect the true conditions prevailing before the cartel formation: "A pre-cartel price is often presumed in legal settings to be the competitive price. 'Cartel members ... enjoy no presumption that they already had market power before the illegal act was committed' (Hovenkamp, 1998:660). However, even if a pre-cartel period was arguably one of oligopolistic tacit pricing

\footnotetext{
${ }^{18}$ Equivalently, in the same constant price elasticity of demand framework, if marginal costs are not identical in both regions, Cournot equilibrium prices will also differ as a direct consequence of equation (1) and using the price in region 2 as a but-for price estimate could again lead to an improper statement of damages.

${ }^{19}$ However, the value of $k$ and therefore $k /(1+k)$ are not independent of the price elasticity of demand,

${ }^{20}$ As quoted by Connor (2006).
} 
conduct, the pre-cartel price is still a reasonable benchmark so long as the competitive determinants of pricing conduct did not change when the cartel was formed."

Also, in Connor (2010, footnote 3 ) it is mentioned that: "...The benchmark may be the purely competitive price, or it may be a somewhat higher price generated by legal tacit collusion by companies in an oligopolistic industry". However, footnote 47 casts some doubt on how he actually interprets the overcharges estimated from the Lerner index in subsequent analyses: "...The Lerner Index is the same as the overcharge, except that it is measured by dividing [the difference between] the market price [and the marginal cost] by the monopoly price instead of the competitive price".

To illustrate the danger of overstating the excess profit when using such a short-cut, we compare the excess profit that would prevail using a simple model of imperfect price competition with differentiated products (see sidebar 2) to the excess profit based on the Lerner index. The related Table 2 provides two sets of calculations. Consider first the "Lerner Index" column with a cartel price overcharge of $k=30 \%$, a but-for price equal to marginal cost, a competitive mark up $m=0$ and a Lerner index $L=\left(p^{m}-c\right) / p^{m}$ equal to $k /(1+k)=23 \%$, which is the excess profit as a percentage of sales. The analysis is different if competition moves away from pure Bertrand competition (with a butfor price equal to marginal cost) because firms differentiate their products, allowing a competitive mark up above zero. We present a simple model of competition with product differentiation in sidebar 2 and the estimated excess profit in Table 2. The corresponding excess profit could drop from $23 \%$ to a value in the interval $16 \%$ to $10 \%$ as shown in Table 2 (the cross elasticity is declining as the production differentiation increases). As we stressed above, the cartel price overcharge and the competitive markup are interdependent values since a higher competitive markup implies a lower cartel overcharge as the cartel will never charge more than the monopoly price.

However, the inverse relation between the competitive mark up and the cartel overcharge has no effect on the Lerner index since this index refers directly to the marginal cost. Table 2 shows that if the Lerner index is used (column "Lerner index") when the competitive markup $m$ is not 0 , the cartel excess profit is overstated, in this example by a factor ranging from $150 \%$ to $230 \%$. This directly translates into overstatements of both the restitution fine and the dissuasive fine benchmarks. 


\section{Sidebar 2: The Bertrand competition model with differentiated products}

A widely used framework to model price competition model with differentiated products is the one proposed by Shubik (1980). We use the version of this model specified in Demange and Ponssard (1985).

There are 2 firms, each one producing a differentiated product.

Marginal costs of production for the firms are identical and constant at $c$.

The demand function $q_{i}$ for firm $i$ is (with $p_{i}$ and $p_{j}$ standing for the price selected by the two firms):

$$
q_{i}=1-b p_{i}+\omega\left(p_{j}-p_{i}\right)
$$

It is characterized by two parameters $b$ and $\omega$. The parameter $b$ is related to the aggregate market price elasticity and the parameter $\omega$ is related to the degree of differentiation of the products (technically, since we are using linear demand functions and not iso-elastic ones, the price elasticity is not constant; it depends on the two selected prices; see the numerical calibration below).

This model can be solved to obtain the competitive outcome $p=p_{j}=p_{i}$ (i.e. the Bertrand Nash equilibrium) and the cartel outcome $p^{m}$ (taken as the monopoly equilibrium for simplicity, which is an upper bound on the effect of a cartel). ${ }^{21}$

For completeness we give the analytical expressions of these two outcomes.

The competitive price is

$$
p^{*}=\left[2(\omega+b)+a+2(\omega+b)^{2} c+\omega(\omega+b) c\right] /\left[4(\omega+b)^{2}-\omega^{2}\right]
$$

The cartel (monopoly) price is

$$
p^{m}=(1+b c) /(1+b)
$$

The numerical values used in the simulation to obtain the results displayed in Table 2 are the following ones. The constant marginal cost $c$ is taken as 1.6 , the parameter $b$ is taken as .25 , and the degrees of differentiation $\omega$ used to generate the cartel overcharge $(20 \%, 15 \%$ and $13 \%)$ are given in the table.

The local price elasticity as the prices changes from $p^{*}$ to $p^{m}$ is defined as $\varepsilon=-\left[\left(q^{m}-q^{*}\right) / q^{*}\right] \Lambda\left(p^{m}-\right.$ $\left.\left.p^{*}\right) / p^{*}\right]$. Observe in Table 2 that it is almost constant as $\omega$ varies.

\footnotetext{
${ }^{21}$ Indeed, Block, Nold and Sidak (1981) show that " a cartel's optimal price is likely to be neither the competitive price nor the price that the cartel would set in the absence of antitrust enforcement but rather an intermediate price that depends on the levels of antitrust enforcement efforts and penalties." Their empirical results "reveal that increasing antitrust enforcement in the presence of a credible threat of large damage awards has the deterrent effect of reducing markups in the bread industry."
} 
Table 2: Comparing the Lerner index short-cut and a formal economic model

\begin{tabular}{|c|c|c|c|c|}
\hline Parameters & $\begin{array}{c}\text { Lerner } \\
\text { index }\end{array}$ & \multicolumn{3}{|c|}{$\begin{array}{c}\text { Imperfect price competition with } \\
\text { differentiated products }\end{array}$} \\
\hline degree of differentiation $\omega$ & Irrelevant & 4 & 2,4 & 2 \\
\hline cartel overcharge $k$ & $30 \%$ & $20 \%$ & $15 \%$ & $13 \%$ \\
\hline competitive mark up $m$ & $0 \%$ & $8 \%$ & $13 \%$ & $15 \%$ \\
\hline local price elasticity $\varepsilon$ & 0.7 & 0.8 & 0.8 & 0.9 \\
\hline $\begin{array}{c}\text { Estimated Excess profit as } \\
\text { a percentage of sales }\end{array}$ & $23 \%$ & $16 \%$ & $12 \%$ & $10 \%$ \\
\hline $\begin{array}{c}\text { overstatement factor } \\
\text { when wrongly using the } \\
\text { Lerner index }\end{array}$ & 1.0 & 1.5 & 2.0 & 2.3 \\
\hline
\end{tabular}

\section{Defining the Benchmarks in a Dynamic Framework}

Cartels operate in a dynamic environment and this should be accounted for in their analysis. As shown below, the analysis of the but-for environment as well as of cartels internal stability is much more complicated in a dynamic framework.

\subsection{The but-for environment in a dynamic framework}

It is well known that dynamic market interactions may yield higher prices than the static competitive prices. ${ }^{22}$ Economic theory defines "tacit collusion" outcomes as the set of non-cooperative market outcomes that can be attained absent explicit collusion, i.e. without explicit agreements between firms, but mimicking collusive outcomes. For instance, Ivaldi et al. (2003) define tacit collusion as follows: "Tacit collusion need not involve any 'collusion' in the legal sense, and in particular need involve no communication between parties. It is referred to as tacit collusion only because the outcome (in terms of prices set or quantities produced, for example) may well resemble that of explicit collusion or even an official cartel." When assessing the "but-for" price, one must therefore be aware of the possibility that tacit collusion equilibrium occurs, which, legally, is not anticompetitive.

The microeconomic analysis of non-cooperative competitive market outcomes in a dynamic framework relies on two main sets of models: repeated games and Markov games. The first strand of that literature considers that dynamic interactions can be interpreted as the repetition of a static competition game. Following Friedman (1971), the "folk theorems" state that in such repeated games, the set of competitive prices may range from the repetition of competitive outcomes to the monopoly

\footnotetext{
${ }^{22}$ See for instance Motta (2004), chap. 4.
} 
price (depending in part on the firms' patience). ${ }^{23}$ This approach relies on the idea that prices above the static competitive price can be the "natural" outcome of non-cooperative strategic interactions when firms realize that lowering the given price would be followed by a price war that would wipe out any further profit: if firms are patient enough, the prospect of losing all further profits (the "punishment") dominates the incentives for a short term price reduction (the "deviation"). The emergence of such equilibria is favored by the existence of some conditions (e.g. complete information on the demand functions and the cost structures, a small number of firms, relatively homogenous products...) In some cases, these conditions would make the consideration of the Folk theorems unavoidable. In other cases, one may consider that these theorems do not apply and that the static equilibrium provides a satisfactory representation of the but-for-world. ${ }^{24}$

The repeated game framework lacks important features to properly characterize industry equilibria in the presence of demand growth and volatility, potential entry, and capacity constraints. In the long run, industry structure is determined by the investment strategies of the firms, in particular by the existence of exogenous or endogenous sunk costs and their implications for entry and exit of players (Tirole 1988, Sutton 1991). ${ }^{25}$ Hence, when assessing the but-for-price, it may be necessary to revisit some basic structural factors underlying the current industry situation. For instance, it may be the case that a more intense competition would lead to a more concentrated industry. Moreover, a more concentrated industry does not necessarily imply higher market power for firms (Sutton, 1991). ${ }^{26}$

The second strand of the literature has designed suitable conceptual tools to deal with issues in dynamic games that cannot be interpreted as repetitions of static games. Baumol, Panzar and Willig (1982) introduced the notion of contestable markets to explain why, though the number of firms on a market may be small, the market outcomes may still be competitive due to the threat of entry. Similar developments can also be used to formalize the creative destruction process imagined by Schumpeter through which the most efficient firm emerges as the dominant firm until it is replaced by an even more efficient one. ${ }^{27}$ The complexity of the competition process in such dynamic games can be illustrated through the Boyer, Lasserre and Moreaux (2011) model for investments in capacity in a

\footnotetext{
${ }^{23}$ Technically, the "folk theorems" apply to games with infinite horizon, that is, indefinitely repeated; however, the result extends to market interactions are repeated over a period long enough for each firm to ignore the date of its exiting the market. Fudenberg and Maskin (1986), for instance extend this result to more realistic frameworks with incomplete information.

${ }^{24}$ This is the view taken in Phlips (1995). This will be the line of thought that will be followed in the next section to characterize the role of fines as deterrent of cartel formation. Observe that this is a conservative view in the sense that it tends to underestimate the but-for price.

${ }^{25}$ For instance, the interaction between demand volatility and industry capacity in a dynamic context is subtle. Consider two firms producing their Cournot equilibrium quantity with no capacity to spare. If a shift in demand occurs such that quantity demanded increases at all price levels, the firms will invest to increase their production capacity. In the meantime, even absent collusive agreement, both firms supply the market given their production capacity, which is below their unconstrained Cournot equilibrium quantity, and the firms thus exert some market power above the level that existed before the increase in demand.

${ }^{26}$ See D'Aspremont and Motta (2000).

${ }^{27}$ See also Ponssard (1991) and Gromb, Ponssard and Sevy (1997).
} 
homogeneous product duopoly facing uncertain demand growth. ${ }^{28}$ Using the concept of Markov Perfect Equilibrium (MPE) introduced and characterized by Maskin and Tirole (1988), they show that equilibirum paths of the investment game may include both preemption (strong competition) episodes and "tacit collusion" episodes (with higher prices) as natural, non cooperative, competitive episodes. Hence, dynamic but-for price and investment patterns may very well be mimicking collusive-like patterns in the absence of cartel behavior, even in homogenous product markets (particularly favorable to strong competition outcomes), and especially in markets or industries with high demand volatility, high market growth and low cost of capital. ${ }^{29}$

These theoretical developments are also playing an increasingly important role in applied industry models. The trend of such applications originated from the work of Erickson and Pakes (1995) who provides a methodology to design realistic models in which the industry structure evolves over time under endogenous entry and exit due to various shocks in the demand or cost functions.

\subsection{Internal cartel stability in a dynamic environment}

As outlined previously, the natural competition price in a dynamic setting can mimic any type of static equilibrium. For example, when a price war prevails, the natural competition price will be quite close to the marginal cost of production. Also, a tacit collusion equilibrium can drive the price up to its monopoly level. Finally, Cournot-type competition has the potential to generate any price level in between. In analyzing the stability of cartels below, we adopt the conservative approach which consists of assuming that the competitive outcome of a dynamic strategic interaction mimics the repetition of the competitive outcomes static strategic interaction.

The characteristics of antitrust policy, and in particular the design of fines, obviously influence cartel stability. In Sidebar 3, we analyze cartel stability by introducing a risk of defection as well as a risk of punishment by antitrust authorities. We consider a hypothetical industry where a given number of firms set up a cartel. In each period, there is an exogenous annual probability of detection $\alpha$ of the cartel $;{ }^{30}$ the firms may either follow the cartel strategy or deviate. If the cartel is detected, the cartel is dissolved and each firm pays a fine $H$ in monetary terms (not in percentage), assumed constant over time. For each firm, we denote the one-period cartel profit as $\pi^{M}$, the one-period deviation profit as

\footnotetext{
${ }^{28}$ In that model, capacity building is achieved through the addition of production units that are durable and lumpy and whose cost is mainly irreversible. While building their capacity over time, firms compete à la Cournot in the product market.

${ }^{29}$ Technically, these conditions increase the discount factor expressed in state space, which in a sense is reminiscent of the role of a high value of $\delta$ in repeated games (see Sidebar 3 below).

${ }^{30}$ Harrington (2004) considers a situation where the probability of cartel detection (and conviction) increases with the magnitude of price changes: bigger price movements are more likely to trigger suspicions and thus detection of the cartel. When the probability of detection is sufficiently sensitive to price increases, the cartel gradually raises price. If, in addition, detection is sufficiently sensitive to price decreases, then deviations are prevented as a sudden price war would trigger suspicion.
} 
$\pi^{D}$ and the one-period but-for competitive profit as $\pi \cdot{ }^{31}$ Deviation makes sense only if $\pi^{D}>\pi^{M}$, a sensible condition. Following the industrial organization repeated game approach to cartel formation and stability (Fudenberg and Maskin 1986; Tirole 1988), we assume that the interactions are repeated over a large (infinite) number of periods and that all firms have the same discount factor $\delta$. We focus on trigger strategies: each player plays the cartel strategy as long as no player has deviated previously; if a cartel member deviates from that strategy at some time, all players play the but-for competitive strategy from then on. If the fine is larger than the dynamic dissuasive fine characterized in Sidebar 3, then at least one firm will deviate from the cartel agreement and thereby trigger a chain reaction of deviations leading to the dismantling of the cartel.

Figure 2 provides a representation of the game tree related to Sidebar 3. The cartel members continue to get the cartel profit as long as no member deviates and the cartel is not detected. As soon as one of these two conditions no longer prevails, each firm is back to the but-for profit. A low value of the fine $H$ (or the probability of detection $\alpha$ ) makes defection less attractive (as long as the cartel members are patient), even if the members are aware that the cartel will eventually be detected. Increasing $H$ (or $\alpha$ ) reduces the stability of the cartel: the fear of defection deters the formation or maintenance of a cartel.

Figure 2: The game tree for cartel formation in a dynamic framework

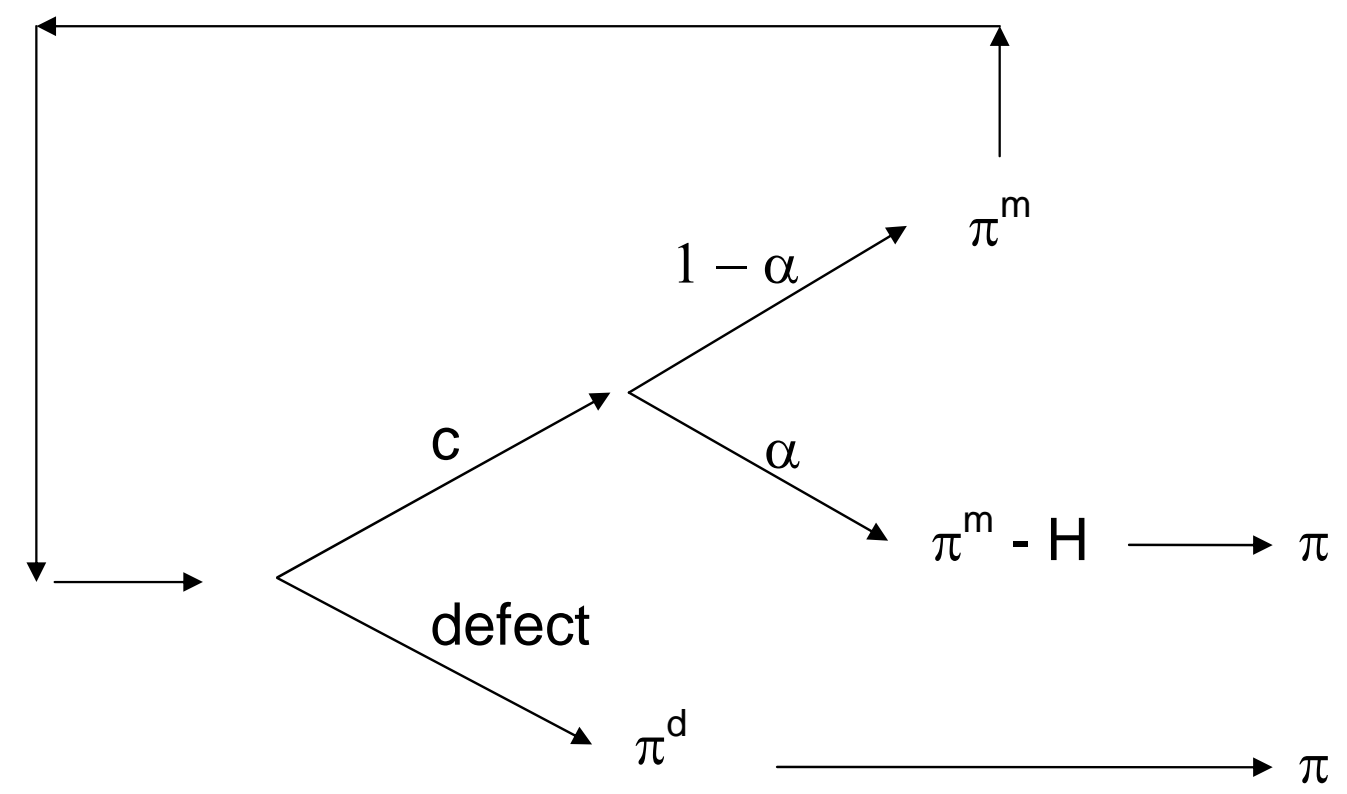

\footnotetext{
${ }^{31}$ Deviation without detection by the authorities implies no antitrust penalty.
} 


\section{Sidebar 3: Minimal deterrent fine in a dynamic environment}

Consider a firm's incentives to deviate at some time, given that all other players play the trigger strategy. If the firm plays the cartel strategy, its discounted profit or its value $V^{M}$ is:

$$
\begin{aligned}
V^{M} & =\pi^{M}+\alpha\left(-H+\frac{\delta}{1-\delta} \pi\right)+(1-\alpha) \delta\left[\begin{array}{c}
\pi^{M}+\alpha\left(-H+\frac{\delta}{1-\delta} \pi\right)+ \\
(1-\alpha) \delta\left(\pi^{M}+\alpha\left(-H+\frac{\delta}{1-\delta} \pi\right)+\ldots\right)
\end{array}\right] \\
& =\frac{\pi^{M}+\alpha\left(-H+\frac{\delta}{1-\delta} \pi\right)}{1-\delta(1-\alpha)}
\end{aligned}
$$

If the firm deviates (and all firms play their competitive strategy thereafter), its value $V^{D}$ is

$$
V^{D}=\pi^{D}+\frac{\delta}{1-\delta} \pi
$$

The fine $H$ will be dissuasive if the firm prefers to deviate, that is if

$$
V^{D}>V^{M} \Leftrightarrow H>\frac{\pi^{M}-\delta(1-\alpha) \pi-\pi^{D}(1-\delta(1-\alpha))}{\alpha}
$$

A sufficient condition for the fine to be dissuasive is that it hinders collusion in the most difficult case of infinitely patient firms $(\delta=1)$ and very low deviation profit $\left(\pi^{D}=\pi^{M}+v_{1}\right.$ where $v_{1}$ is positive but arbitrarily small. This condition is equivalent to (with $\Delta \pi=\pi^{M}-\pi$ ):

$$
H=\frac{(1-\alpha)}{\alpha} \Delta \pi+v_{1}
$$

Or, expressed as a percentage of annual sales $S$ :

$$
H / S=f^{D}=\frac{(1-\alpha)}{\alpha}(\Delta \pi / S)
$$

Hence, a fine slightly larger than $(1-\alpha) / \alpha$ times the annual incremental cartel profit deters the formation or maintenance of a cartel, whatever its duration. ${ }^{32}$ We refer to this fine as the "dynamic dissuasive fine". For instance, if the annual probability of detection is estimated at $15 \%$, a fine equal to 5.7 times the annual incremental profit is dissuasive even under the most pessimistic or difficult

${ }^{32}$ Note that, even absent internal stability problems, a necessary condition for a cartel to be profitable is that the expected profit of each firm is higher than the competitive profit, that is, given the notations of sidebar 3 , $\pi^{M}-\alpha H>\pi$. This implies that a fine $H>\left(\pi^{M}-\pi\right) / \alpha$ will be deterrent at any time, and in any condition. This fine is independent of the duration of the cartel. 
conditions (very patient firms, low value of deviation); that is, if the net annual incremental profit is $7 \%$ of sales, then a fine of $40 \%$ of annual affected sales would be dissuasive.

Note that the formula we obtain for the dynamic dissuasive fine differs from the static dissuasive fine obtained in Sidebar 1. In particular, the dynamic dissuasive fine is equal to the static dissuasive fine minus $\Delta \pi / S$. The excess profit and probability of detection are defined on the same period, but this period need not be the duration of the cartel. A fine above the dynamic dissuasive fine will deter the formation of cartels whatever their contemplated durations. In reality, we assume in deriving our results that a cartel member can defect at any time under the threat of detection and prosecution, which is certainly a reasonable assumption. A fine lower than the dynamic dissuasive fine will not deter cartel formation, and the observed durations will depend on the probability of detection.

The formula of the dynamic dissuasive fine obtained in our dynamic model is rather robust. First, we define this formula with very conservative assumptions: a deviation is assumed to be barely profitable, as the deviation profit $\pi^{d}$ is set equal to the collusion profit $\pi^{m}$; second, the firms are assumed to be extremely patient, as $\delta=1$. Relaxing either of these two assumptions would reduce the optimal level of the dissuasive fine. Third, we assume that following a deviation, collusion can never be achieved again; relaxing this assumption would increase the probability of deviation and therefore of instability of the cartel, thereby allowing a reduction in the dissuasive fine. Fourth, we assume that deviating firms do not pay the fine even if the cartel is detected at that time; relaxing this assumption would reduce the incentive to deviate, thereby justifying an increase of the dissuasive fine. ${ }^{33}$ However, the increase in the fine would be relatively low, namely by a factor $1 /(1-\alpha)$ (that is, if the probability of detection is assumed to be $\alpha=15 \%$, the fine increase would be about $18 \%$ ), but this is negligible as soon as the deviation profit becomes significantly higher than the collusion profit, or the discount factor is lower than $1 .^{34}$ Fifth, our analysis can be extended straightforwardly to comprehensive concepts of dissuasive fine, defined as the monetary equivalent of all penalties including financial sanctions on corporations and individuals as well as personal sanctions such as debarment and prison terms for individuals, and illicit profits, defined as including harm to the economy in general.

Harrington (2004) develops a more complex dynamic model of cartel stability. He models the sanction as the sum of a fixed fine and damages, which are proportional to the (present and past)

\footnotetext{
${ }^{33}$ A deviating firm can still be fined for its participation in the cartel when, for instance, communication prior to the price-setting stage (for instance, records of the firm's participation to previous meetings) provides evidence (the "smoking gun") of participation to the agreement: see Harrington (2004) or Aubert, Rey and Kovacic (2006). Note that, integrating our two conservative assumptions (deviation profit equal to the collusion profit, and firms infinitely patient) in the model of Aubert, Rey and Kovacic (2006), in absence of a leniency program, would yield the same dissuasive fine than ours.

${ }^{34}$ Note also that, if price variations increased the suspicion of the antitrust authorities (as in Harrington 2004), a price war would increase the risk of detection and fine: in that case, if the deviating firm is fined, the incentive to deviate is actually reduced: hence the importance of establishing leniency programs in that case.
} 
welfare losses caused by the cartel. ${ }^{35}$ The damages are cumulative: the amount of damages to be paid if the cartel is detected is the sum of the welfare loss in the current period (possibly multiplied by a given factor) plus the damages in the previous periods, discounted to take account of the difficulty to evaluate past welfare losses. With a constant per-period probability of detection, damages grow over time and the collusive payoff is declining at a faster rate than is the deviation payoff. Hence the cartel becomes less stable and has to lower its prices to avoid deviations.

Along similar lines, Hinloopen (2006) computes the optimal fine in a model that allows the probability of detection to vary across periods: "[fines] and detection probabilities appear to be substitutable instruments as an increase in either reduces [the prospect for cartels]. At the same time the two instruments are complementary in that an increase in prospective fine payments yields more effect the higher are per-period detection probabilities". ${ }^{36}$ This analysis can be useful as we may expect that the annual probability of detection of a cartel increases over the cartel lifetime. One reason for this is that leniency programs are more attractive as the cartel duration increases.

\subsection{Effectiveness of a restitution fine policy}

The previous analysis suggests that what is traditionally known as the restitution fine may actually be dissuasive in a dynamic context, at least after some time. In this section, we gauge the efficiency of a policy of inflicting the restitution fine to any convicted cartel. To this end, suppose a cartel has been going on for $n$ years and is contemplating to go on for one more year. During this additional year, this cartel will be detected with probability $\alpha$ and, if detected and imposed the restitution fine, it will pay $[(n+1) \Delta \pi]$ or a percentage $([(n+1) \Delta \pi] / S)$ of its annual sales. If it goes on one more year, the expected net additional or incremental illicit profit of the cartel is:

$$
\Delta \pi-\alpha(n+1) \Delta \pi=\Delta \pi[1-\alpha(n+1)]
$$

The restitution fine is thus dissuasive if $n+1 \geq 1 / \alpha$. If the annual probability of detection is $\alpha=15 \%$, then the restitution fine becomes dissuasive after six (more precisely 5.67) years as the expected net incremental profit of one additional year turns out to be negative: the cartel would rationally self-dissolve if not detected. If $\alpha=20 \%$, then the restitution fine becomes dissuasive after four years. The restitution fine is therefore too low to be dissuasive for shorter-lived cartels, and far above the deterrent level for longer-lived cartels.

However, in a world where all cartels are stable and not dissolved unless detected, all cartels eventually end up being detected if the probability of detection is strictly positive. In such a world, the

\footnotetext{
${ }^{35}$ This model is designed to illustrate the American system of fines.

${ }^{36}$ See also Garoupa (2001).
} 
restitution fine ensures that the total illegal profits of all cartels are seized back in the long run provided the date of birth and effects of cartels can be correctly assessed. ${ }^{37}$

\subsection{The role of leniency and compliance programs}

Leniency programs modify the deterrence properties of fines. ${ }^{38}$ Leniency programs make enforcement more effective, but they may also induce collusion since they decrease the cost of misbehavior. A leniency program might lead firms to deviate from the cartel agreement, thus reducing the duration of cartels and also the cost of investigations if denouncement can be made sufficiently truthful. However, a leniency program also reduces the expected cost of anticompetitive behavior, and may thereby increase the ex-ante incentives of firms to participate in a cartel. However, if the program is optimally chosen by a competition authority, the former effect dominates and the leniency program improves welfare. ${ }^{39}$ In that vein, some researchers have considered the possibility of rewarding whistle-blowers in leniency programs, thus increasing individual incentives to deviate and reducing the cartel stability. For instance, Aubert, Rey and Kovacic (2006) argue that rewarding firms or even individual informants for denouncing cartels, including firm employees, can deter collusion in a more effective way.

A question of interest is whether a commitment to antitrust compliance within a company should be used as mitigating factor. As acknowledged by Wils (2006), "If they reflect a genuine commitment to antitrust compliance at the highest levels within the company, and are well-designed, compliance programmes can no doubt be very useful both to prevent antitrust violations and to detect such violations as early as possible." Hence, the use of compliance programs as attenuating factors is a priori justified by the argument that they contribute to the reduction of the harm caused to society by cartels. However, promising fine reductions to firms that introduce a compliance program would reduce ex ante the deterrent effect of the fine. Perhaps, using the absence of a credible compliance program as an aggravating factor might be more efficient in deterring competition infringements.

\section{The Optimal Level of Fines}

So far, we have provided a theoretical discussion of the optimal characteristics of fines in cartel cases. The next step is to assess the efficiency of fines actually imposed by Antitrust authorities. This is obviously a very difficult task. We will base our analysis on the empirical study by Combe and

\footnotetext{
${ }^{37}$ Note however that the interest generated by the illicit profits should be, but usually are not included in the fines.

${ }^{38}$ Note that the number of cartels convicted has increased since the introduction of leniency programs. In Europe for instance, from 1996 to 2008, 6.25 cartels were convicted on average every year, while this rate was 1.4 per year before 1996.

${ }^{39}$ See Motta and Polo (2003).
} 
Monnier (2010), which is to our knowledge the first attempt to provide such an assessment. We will assess how their results would be modified should their analysis be based on our definition of the optimal fine.

Combe and Monnier (2010) analyze 64 cartels fined by the European Commission from 1975 (the Preserved Mushrooms cartel) to 2009 (the Marine Hose cartel). Actually, 55 of these cases occurred after 2001 that is, at the precise time fines started increasing dramatically. They compared the actual fines with their estimates of both the restitution fine and the optimal fine. The parameters in Table 3 are defined on an annual basis and allow the authors to derive two bounds for the cartel annual excess profit for each of the 64 cases, depending on the value of the demand elasticity, $\varepsilon=2$ or $\varepsilon=0$. This annual excess profit is then used to determine benchmarks: ${ }^{40}$ a lower and higher benchmark for the restitution fine, which corresponds to the annual excess profit as a percentage of cartel sales times the duration of the cartel; a lower and higher benchmark for the dissuasive fine, which corresponds to the two bounds of the restitution fine, as defined above, divided by the annual probability of detection.

Table 3: Combe and Monnier methodology

\begin{tabular}{|c|c|c|}
\hline Parameters & Methodology & Indicator \\
\hline Cartel overcharge (denoted $k$ ) & $\begin{array}{l}\text { Based on Connor and } \\
\text { Bolotova (2006) or } \\
\text { authors' own estimate }\end{array}$ & $\begin{array}{c}+20 \% \text { for national cartels, } \\
+30 \% \text { for international ones; } \\
\text { Direct estimate of price increase in } \\
12 \text { cases out of } 64\end{array}$ \\
\hline $\begin{array}{l}\text { Competitive markup } \\
\quad(\text { denoted } m)\end{array}$ & $\begin{array}{l}\text { authors' own estimate, } \\
\text { case by case evaluation }\end{array}$ & $\begin{array}{l}\text { Operating result/turnover of cartel } \\
\text { members or industry leaders } \\
\text { (average over } 5 \text { years). }\end{array}$ \\
\hline $\begin{array}{l}\text { Price elasticity of demand } \\
(\text { denoted } \varepsilon)\end{array}$ & Sensitivity analysis & Two extreme values: $\varepsilon=0$ and $\varepsilon=2$ \\
\hline Affected market (denoted $S$ ) & $\begin{array}{l}\text { Direct evaluation from } \\
\text { the cases }\end{array}$ & $\begin{array}{l}\text { Annual turnover of the cartel } \\
\text { members on the affected geographic } \\
\text { and product market }\end{array}$ \\
\hline $\begin{array}{l}\text { Duration of the cartel } \\
\quad(\text { denoted } n)\end{array}$ & $\begin{array}{l}\text { Direct evaluation from } \\
\text { the cases }\end{array}$ & $\begin{array}{l}\text { Date of first piece of evidence } \\
\text { /detection date or natural death of } \\
\text { the cartel before its detection }\end{array}$ \\
\hline $\begin{array}{l}\text { Probability of detection } \\
\quad(\text { denoted } \alpha)\end{array}$ & $\begin{array}{c}\text { Based on Bryant and } \\
\text { Eckart (1991), Combe et } \\
\text { al (2006) }\end{array}$ & Probability of $15 \%$ \\
\hline
\end{tabular}

They define the restitution fine as the annual excess profit times the duration of the cartel (assuming stationary excess profits). As for the dissuasive fine, they define it as the restitutive fine divided by the annual probability of detection. While their definition of the restitution fine fits more or

\footnotetext{
${ }^{40}$ The benchmarks which are the most favorable to the industry are obtained with $\varepsilon=2$. This is referred to as the "lower" benchmarks by Combe and Monnier.
} 
less in our static framework, their approach to define the dissuasive fine is more questionable. Instead of defining their dissuasive fine as the total excess profit over the whole duration of the cartel divided by the more appropriate overall n-year probability of detection $\alpha_{n}$ (the overall n-year static dissuasive fine), they use total excess profit over the whole duration of the cartel divided by the annual probability of detection $\alpha_{1}$. Table 4 summarizes these various approaches and labels each of them for future reference.

Table 4: Comparing different benchmarks for fines for a given $\Delta \pi$

\begin{tabular}{|l|c|c|c|c|}
\hline Benchmarks & $\underline{\text { label }}$ & $\underline{\text { Definition }}$ & $\underline{\text { Relative to F1 }}$ & $\frac{\text { Relative to F3 }}{1}$ \\
\hline Restitution fine & F1 & $n \Delta \pi$ & $n \alpha /(1-\alpha)$ \\
\hline Combe and Monnier dissuasive fine & F2 & $n \Delta \pi / \alpha$ & $1 / \alpha$ & $n /(1-\alpha)$ \\
\hline Our dynamic dissuasive fine & F3 & $(1-\alpha) \Delta \pi / \alpha$ & $(1-\alpha) / n \alpha$ & 1 \\
\hline Overall n-year static dissuasive fine & $\mathrm{F} 4$ & $n \Delta \pi / \alpha_{n}$ & $1 / \alpha_{n}$ & $n \alpha / \alpha_{n}(1-\alpha)$ \\
\hline
\end{tabular}

In the sample of cases considered by Combe and Monnier, the average duration of cartels is 7.3 years and the median is 5.6 years. To put it simply, the order of magnitude in the overstatement of their dissuasive fine benchmark (using $n=7$ ) with respect to the proper dissuasive fine is F2/F3 $=n /(1-$ $\alpha)=8.2$, which increases with both $n$ and $\alpha$.

To get an intuitive understanding of the major impact of these different formulations, Graph 1 gives the relative positioning of each benchmark for $\alpha=15 \%$, a given similar value of $\Delta \pi$, and the dynamic dissuasive fine F3 normalized at 1 . 


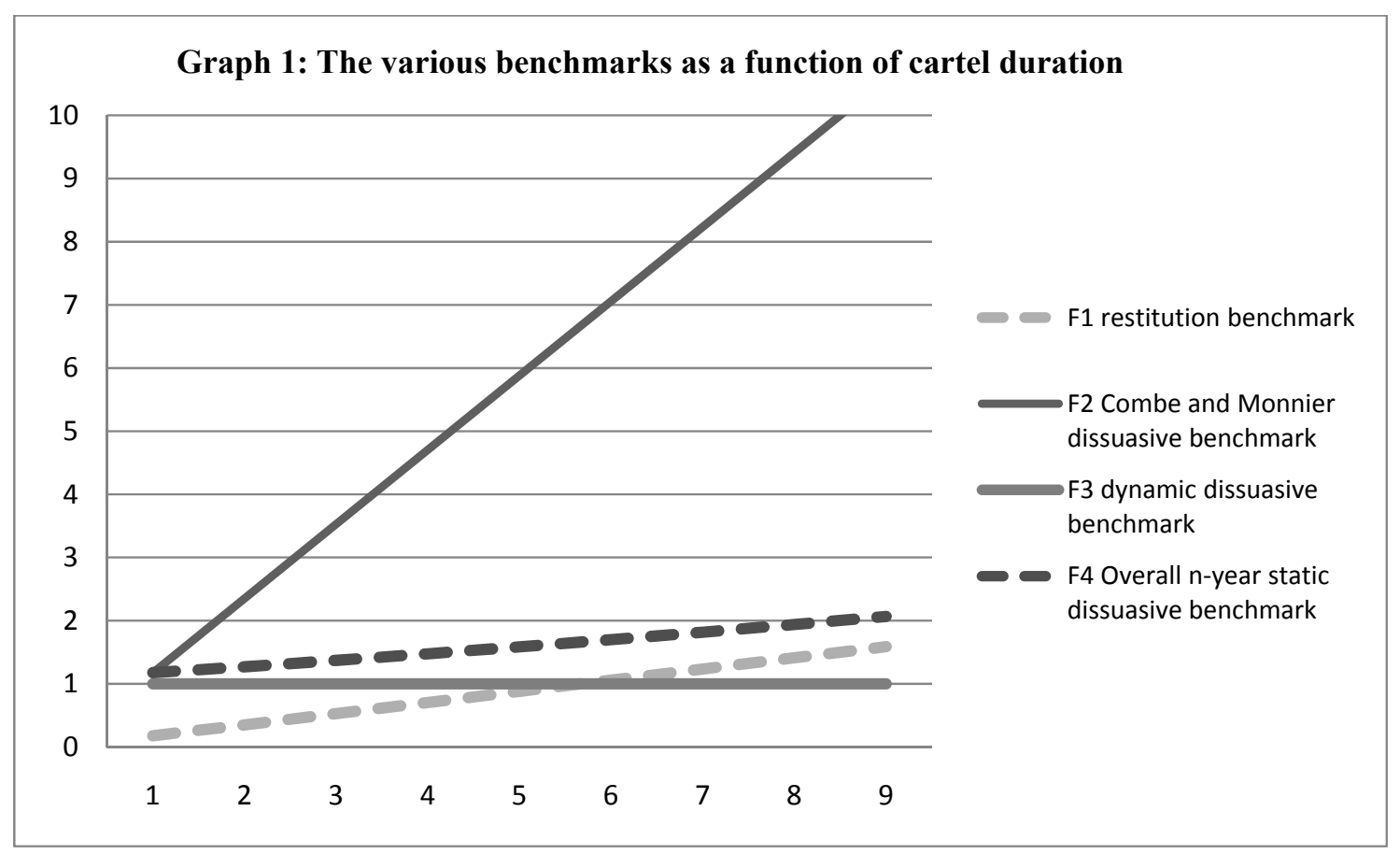

For cartel with duration less than 6 years (more precisely for $n<5.67$ ), the dynamic dissuasive fine benchmark F3 is above the restitutive fine benchmark F1, while the reverse is true for cartels with duration of 6 years and longer. If it is important to satisfy both deterrence and restitution criteria, then the fine benchmark could be set at the highest of the two levels: in the example of Graph 1, this translates into the use of the dynamic dissuasive fine for cartels whose duration is less than five or six years and the restitutive fine for cartels of longer duration. Note that an increase in the probability of detection (for instance due to a leniency program) reduces F2, F3 and F4. However, as mentioned above the ratio $\mathrm{F} 2 / \mathrm{F} 3$ increases.

For each of the 64 cartels, Combe and Monnier derive lower benchmarks (by taking $\varepsilon=2$ ) for the restitution and the dissuasive fines associated with their model. They provide a graph depicting the position of each cartel indicating whether the fine it was imposed is higher or lower than the respective benchmarks. If the position of a fine is above the relevant benchmark, it may be considered as restitutive or dissuasive, respectively. The overall conclusion of the authors is that, at best, $50 \%$ out of the 64 fines lie above the restitution benchmark, while only one out of 64 lies above the dissuasive benchmark.

To make a complete comparison with our own benchmarks, one would need to have their detailed database and redo some of the calculations, in particular and most importantly the $\Delta \pi$ estimates. Combe and Monnier estimates rely in part on Connor's works to assert minimal cartel overcharge estimates of $20 \%$ for domestic cartels and 30\% for international cartels. Boyer and Kotchoni (2011), using a Connor database, updated but similar otherwise to that used by Connor 
(2010), found maximal cartel overcharge bias-corrected estimates of $12.6 \%$ for domestic cartels and $14.8 \%$ for international cartels. ${ }^{41}$

In Table 5, assuming a mean cartel overcharge of $13 \%$, we rescaled the range of the competitive markup to an interval $17 \%$ to $27 \%$ instead of a uniform $10 \%$ so that the total margin over marginal costs remains constant. Table 5 presents the cartel excess profit as a percentage of sales and the values of benchmarks F1, F2, F3 and F4 obtained from Table 4.

This table should be read as follows. Columns are paired: columns 1 and 3 (in italics) represent the case with $k+m=40 \%$, while columns 2 and 4 represent the case $k+m=30 \%$. Combe and Monnier consider cartel overcharges between 20\% and 30\% (in line with Connor), while we use a uniform cartel overcharge of 13\% (in line with Boyer and Kotchoni). But the table allows a full comparison of the different cases. Consider the comparison of paired columns 2 and 4 . The cartel excess profit falls from $12 \%$ to $7 \%$ of sales (using the calculations of Sidebar 1, as in Combe and Monnier ${ }^{42}$ when the cartel overcharge goes from $20 \%$ to $13 \%$. The Combe and Monnier dissuasive fine F2, together with the assumed $20 \%$ mean cartel overcharge estimate (column 2), reaches $465 \%$ of annual affected sales, while our dynamic dissuasive fine F3, together with our assumed mean cartel overcharge estimate of $13 \%$, reaches $40 \%$ of annual affected sales. The Combe and Monnier dissuasive fine F2, together with our 13\% mean cartel overcharge estimate (column 4), would reach $279 \%$ of annual affected sales, while our dynamic dissuasive fine F3, together with their assumed mean cartel overcharge estimate of $20 \%$, would reach $66 \%$ of annual affected sales. Our dynamic dissuasive fine F3, together with our mean cartel overcharge estimate, is therefore more than 10 times lower than the Combe and Monnier dissuasive fine F2, with their assumed mean cartel overcharge estimate (both appear in bold in Table 5).

\footnotetext{
${ }^{41}$ Boyer and Kotchoni (2011) controls for heterogeneity, asymmetry, outliers and sample selection problems that are inherent to the raw overcharge estimates data.

${ }^{42}$ As mentioned before, Sidebar 1 is taken from Buccirossi and Spagnolo (2007) who do not condone its use when a leniency program is in place. They write: “... this standard methodology is appropriate when there is no effective leniency program in place, but it gives misleading results when such a program is in place, such as in the US after 1993 and in the EU after 1996." Our approach described above in Figure 2 and Sidebar 3 does not rest on the existence of such a leniency program insofar as a deviation by one firm may occur without the cartel being revealed or detected.
} 
Table 5: Comparison of the various benchmarks (with demand elasticity $\varepsilon=2$ )

\begin{tabular}{|c|c|c|c|c|c|}
\hline & \multirow[t]{2}{*}{ Parameters } & \multicolumn{2}{|c|}{$\begin{array}{c}\text { With } \\
\text { Combe and Monnier } \\
\text { cartel overcharge }\end{array}$} & \multicolumn{2}{|c|}{$\begin{array}{c}\text { With } \\
\text { Boyer and Kotchoni } \\
\text { cartel overcharge }\end{array}$} \\
\hline & & (1) & (2) & (3) & (4) \\
\hline & $\begin{array}{c}\text { cartel } \\
\text { overcharge } k\end{array}$ & $30 \%$ & $20 \%$ & $13 \%$ & $13 \%$ \\
\hline & $\begin{array}{l}\text { competitive } \\
\text { markup } m\end{array}$ & $10 \%$ & $10 \%$ & $27 \%$ & $17 \%$ \\
\hline & $\begin{array}{c}\text { Excess profit } \\
\text { as a percentage } \\
\text { of sales } \\
\text { (Buccirossi and } \\
\text { Spagnolo) } \\
\end{array}$ & $13 \%$ & $12 \%$ & $5 \%$ & $7 \%$ \\
\hline & $\begin{array}{c}\text { Annual } \\
\text { probability of } \\
\text { detection }\end{array}$ & $15 \%$ & $15 \%$ & $15 \%$ & $15 \%$ \\
\hline & $\begin{array}{l}\text { cartel duration } \\
\text { (years) }\end{array}$ & 6 & 6 & 6 & 6 \\
\hline \multirow{4}{*}{$\begin{array}{l}\text { Fines as \% of } \\
\text { annual sales }\end{array}$} & Restitution F1 & $76 \%$ & $70 \%$ & $29 \%$ & $42 \%$ \\
\hline & $\begin{array}{c}\text { C\&M } \\
\text { dissuasive F2 }\end{array}$ & $503 \%$ & $465 \%$ & $196 \%$ & $279 \%$ \\
\hline & $\begin{array}{l}\text { Our dynamic } \\
\text { dissuasive F3 }\end{array}$ & $71 \%$ & $66 \%$ & $28 \%$ & $40 \%$ \\
\hline & $\begin{array}{l}\text { Overall n-year } \\
\text { dissuasive F4 }\end{array}$ & $121 \%$ & $112 \%$ & $47 \%$ & $67 \%$ \\
\hline
\end{tabular}

We can consider similarly the paired columns 1 and 3 . The cartel excess profit falls from $13 \%$ to $5 \%$ of sales when the cartel overcharge goes from $30 \%$ to $13 \%$. The Combe and Monnier dissuasive fine F2 together with their assumed 30\% mean cartel overcharge estimate (column 1) reaches 503\% of annual sales, while our dynamic dissuasive fine F3 together with our assumed mean cartel overcharge estimate of $13 \%$ reaches $28 \%$ of annual sales. Hence, our dynamic dissuasive fine F3 together with our mean cartel overcharge estimate is about 18 times lower than the Combe and Monnier dissuasive fine F2 with their assumed mean cartel overcharge estimate (both appear underlined in Table 5). ${ }^{43}$

\footnotetext{
${ }^{43}$ Assuming a lower probability of detection (say $5 \%$, a very pessimistic assumption compared to the average $15 \%$ assumption in the literature) increases the level of all fines, except the restitution fine F1. However, the ratio between F2 and F3 remains in the same range. Considering the comparison of paired columns 2 and 4, where the total markup of the cartel is assumed to be $40 \%$, the Combe and Monnier dissuasive fine F2, together with their assumed $20 \%$ mean cartel overcharge estimate (a case similar to column 2), reaches $1394 \%$ of the annual affected sales, while our dynamic dissuasive fine F3, together with our assumed mean cartel overcharge estimate of $13 \%$, reaches $133 \%$ of annual affected sales, that is approximately 10 times lower than F2. We can
} 
If we consider the value of the demand elasticity used by Combe and Monnier to define their maximal benchmarks $(\varepsilon=0)$ for which less than $19 \%$ of fines meet the restitutive benchmark and none of them meet the dissuasive benchmark, then Table 6 presents the cartel excess profit as a percentage of sales and the values of F1, F2, F3 and F4 over the values of the parameters. The structure of the table is the same as that of previous table.

Considering paired columns 2 and 4 in Table 6, we observe that our dynamic dissuasive fine F3 together with our assumed cartel overcharge is more than 10 times lower than the Combe and Monnier dissuasive fine F2 together with their assumed cartel overcharge (both appear in bold in Table 6). Similarly, if we consider paired columns 1 and 3, we observe that our dynamic dissuasive fine F3 together with our assumed cartel overcharge is more than 14 times lower than the Combe and Monnier dissuasive fine F2 together with their assumed cartel overcharge (both appear underlined in Table 6).

Another way of looking at our results is as follows: we recommend dissuasive fine levels ranging from $28 \%$ to $65 \%$ of annual sales, while Combe and Monnier would recommend dissuasive fine levels ranging from $465 \%$ to $923 \%$ of annual sales. These values are of course contingent on the parameters used in the analysis.

consider similarly the paired columns 1 and 3, where the total cartel markup is $30 \%$. F2 reaches approximately 15 times the annual sales, while our dynamic dissuasive fine F3 reaches 0.93 times the annual sales: the ratio is about 16. By contrast, increasing the probability of detection reduces the amount of fines F2, F3 and F4 and increases the ratio: assuming annual probability of detection of $25 \%$ yields the following figures: for columns 2 and $4, \mathrm{~F} 2=372 \%$ and $\mathrm{F} 3=21 \%$ (a ratio of 17 ), and for columns 1 and $3, \mathrm{~F} 2=400 \%$ and $\mathrm{F} 3=15 \%$ (a ratio of 27 ). 
Table 6: Comparison of the various benchmark (with demand elasticity $\varepsilon=0$ )

\begin{tabular}{|c|c|c|c|c|c|}
\hline & \multirow[t]{2}{*}{ Parameters } & \multicolumn{2}{|c|}{$\begin{array}{c}\text { With } \\
\text { Combe and Monnier } \\
\text { cartel overcharge }\end{array}$} & \multicolumn{2}{|c|}{$\begin{array}{c}\text { With } \\
\text { Boyer and Kotchoni } \\
\text { cartel overcharge }\end{array}$} \\
\hline & & (1) & (2) & (3) & (4) \\
\hline & $\begin{array}{c}\text { cartel } \\
\text { overcharge } k\end{array}$ & $30 \%$ & $20 \%$ & $13 \%$ & $13 \%$ \\
\hline & $\begin{array}{l}\text { competitive } \\
\text { markup } m\end{array}$ & $10 \%$ & $10 \%$ & $27 \%$ & $17 \%$ \\
\hline & $\begin{array}{c}\text { Excess profit as } \\
\text { a percentage of } \\
\text { sales } \\
\text { (Buccirossi and } \\
\text { Spagnolo) } \\
\end{array}$ & $23 \%$ & $17 \%$ & $12 \%$ & $12 \%$ \\
\hline & $\begin{array}{c}\text { Annual } \\
\text { probability of } \\
\text { detection }\end{array}$ & $15 \%$ & $15 \%$ & $15 \%$ & $15 \%$ \\
\hline & $\begin{array}{l}\text { cartel duration } \\
\text { (years) }\end{array}$ & 6 & 6 & 6 & 6 \\
\hline \multirow{4}{*}{$\begin{array}{l}\text { Fines as \% of } \\
\text { annual sales }\end{array}$} & Restitution F1 & $138 \%$ & $100 \%$ & $69 \%$ & $69 \%$ \\
\hline & $\begin{array}{c}\text { C\&M } \\
\text { dissuasive F2 }\end{array}$ & $\underline{923 \%}$ & $667 \%$ & $460 \%$ & $460 \%$ \\
\hline & $\begin{array}{c}\text { Dynamic } \\
\text { dissuasive F3 }\end{array}$ & $131 \%$ & $94 \%$ & $65 \%$ & $65 \%$ \\
\hline & $\begin{array}{l}\text { Overall n-year } \\
\text { dissuasive F4 }\end{array}$ & $222 \%$ & $161 \%$ & $111 \%$ & $111 \%$ \\
\hline
\end{tabular}

In the following graphs we compare the results of Combe and Monnier with these revised benchmarks respectively for the restitution and (dynamic) dissuasive fines. The graphs correspond to the lower benchmarks of Combe and Monnier $(\varepsilon=2)$. To be precise, following our approach, each point representing a given cartel on the graph would be repositioned upwards, most of the time by a significant factor, typically (but not necessarily) of between 10 and 14. But this would require an access to their database as well as some corrections we would like to make to their calculations of the but-for competitive mark-ups, which would typically increase the mark-ups for the reasons discussed above and therefore reduce the cartel overcharge estimates. Alternatively, we can apply a reduction of the benchmark lines to account for the significantly reduced restitutive and dissuasive benchmarks that our results suggest. Although this approach is not as rigorous as the alternative, it will most likely give very similar results. 
Graph 2 (Combe and Monnier):

The position of the 64 cartel cases relative to the benchmarks

\section{Factor $1 / 2$}

Factor $1 / 10$

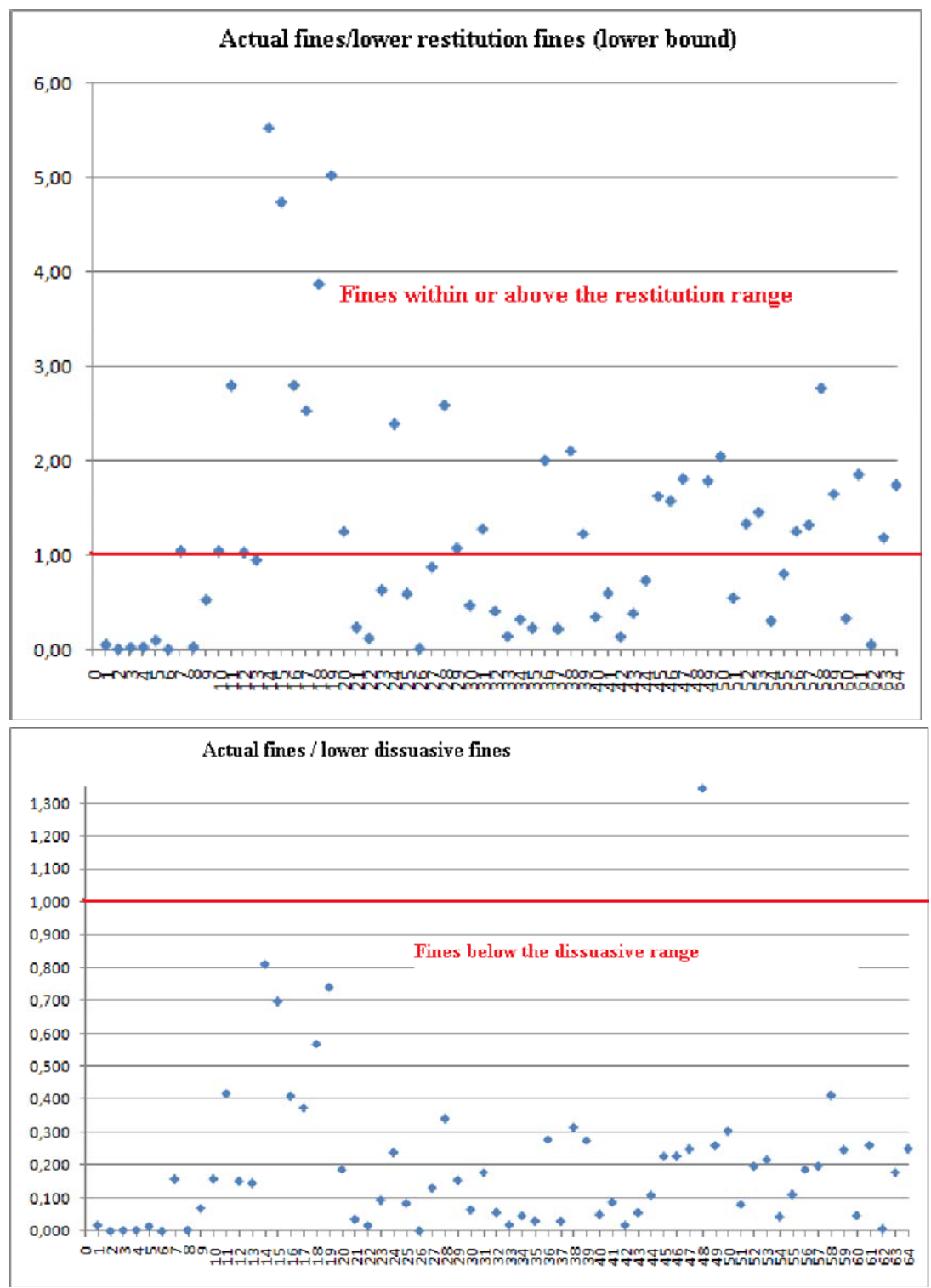

The ratio of fines which are above the restitution fine benchmark increases from $50 \%$ to $65 \%$ if we use a reduction factor of 2 (conservative). If we use an overall overstatement factor of 10 (conservative), the ratio of fines which are above the dissuasive fine benchmark increases from $1.5 \%$ to $56 \%$. If we were to use a less conservative correction factor, the percentage of fines that would end up above the restitution benchmark and the deterrence benchmark respectively would of course increase, possibly significantly. 


\section{Conclusion}

The current orientation of antitrust authorities is to give more importance to deterrence when applying cartel fines. There are a number of potential traps one should avoid in determining dissusive fines, such as: first, using the Lerner index as a short-cut for the excess profit, thus neglecting both the existence of a competitive mark-up (i.e. a but-for price different than the marginal cost) and the demand elasticity (note that the Folz report ${ }^{44}$ strongly invites the antitrust authority to use the demand elasticity); second, confusingly applying a static model to define a benchmark for dissuasive fines, such as dividing the cartel excess profit over the cartel duration by the annual probability of detection; at the very least one should divide the cumulative illicit profits by the overall n-year probability of detection over that duration.

We showed that a proper dynamic analysis of cartel stability suggests using as a dissuasive fine benchmark the annual excess profit times the annual probability of not being detected divided by the annual probability of being detected. This analysis has been developed in the context of so-called "repeated games", while taking very conservative views such as taking the static equlibrium as the competitive outcome and considering very patient firms. In some industries, with a significant level of market concentration, the competitive outcome could be closer to the collusive equilibrium than to the static equilibrium. In such cases one would need to develop dynamic models to grasp the specificities of these industries.

The co-existence of two possible objectives such as restitution and deterrence may create confusion in setting fines. The idea that restitution fine are not dissuasive has been used as an argument in favor of increasing fines above recent levels. This argument is clearly incorrect as soon as the duration of the cartel exceeds about 5 or 6 years. Over such duration restitution fines are overdeterrent.

The most effective and politically acceptable policy might be to set the fines at the highest of the two values: the dynamic dissuasive fine F3 and the restitutive fine F1. In the example of Graph 1, this translates into the use of the dynamic dissuasive fine benchmark for cartels whose duration is less than five or six years (more precisely 5.67 years) and the restitutive fine benchmark for cartels of longer duration.

We have shown that the dissuasive benchmark measured by Combe and Monnier (2010) should be reduced by a factor no smaller than 10. This suggests that, considering the sample of 64 cartels studied by Combe and Monnier, $65 \%$ of the fines imposed by the European Commission in

\footnotetext{
${ }^{44}$ Folz, Raysseguier and Schaub (2010), Rapport sur l'appréciation de la sanction en matière de pratiques anticoncurrentielles.
} 
recent years are above the properly defined restitutive benchmark and $56 \%$ of them are above the properly defined dissuasive benchmark.

More generally the determination of dissuasive fines should be done in the perspective of selecting the best combination of policy instruments. For instance, leniency programs must form an integral part of the analysis of cartel stability: a proper leniency program is likely to increase the probability of detection and conviction (hence making the overstament of F2 with respect of F3 even more problematic), and as such would allow a reduction in dissuasive fine levels. 


\section{References}

Aubert, C., Rey, P., and W. Kovacic (2006) "The Impact of Leniency and Whistle-Blowing Programs on Cartels", International Journal of Industrial Organization, 24, 1241-1266.

Baumol, W., J. Panzar and R. Willig (1982) Contestable markets and the Theory of Industry Structure New York: Harcourt Brace Jovanovich.

Becker, G (1968) “Crime and Punishment: An Economic Approach" Journal of Political Economy 76: 169- 217.

Bernheim, B.D. and M. Whinston (1990) "Multimarket Contact and Collusive Behavior", RAND Journal of Economics, 21, pp. 1-26.

Bernheim, B. Douglas (2002). Expert Report of B. Douglas Bernheim, In Re Vitamins Antitrust Litigation, MDL No. 1285, U.S. District Court for the District of Columbia.

Block M., Nold F. and Sidak J. (1981), "The Deterrent Effect of Antitrust Enforcement", Journal of Political Economy, 89, 429-445.

Borenstein, S., J. Bushnell and C. Knittel (1997), "A Cournot-Nash Equilibrium Analysis of the New Jersey Electricity Market”, University of California Energy Institute.

Boyer, M. and R. Kotchoni (2011), "The Econometrics of Cartel Overcharges", working paper CIRANO scientific series 2011s-35.

Boyer, M., P. Lasserre, M. Moreaux (2011), “A Dynamic Duopoly Investment Game without Commitment under Uncertain Market Expansion”, CIRANO, 2011, 50 pages.

Boyer, M., Lewis, T.R. and W.L. Liu (2000), "Setting standards for credible compliance and law enforcement", Canadian Journal of Economics 33(2), 319-340.

Bryant, P. and W. Eckart (1991), "Price fixing: the probability of getting caught", Review of Economics and Statistics, 73, 531-540.

Buccirossi, P. and G. Spagnolo (2007) "Optimal Fines in the Era of Whistleblowers: Should Price Fixers Still Go To Prison?", pp. 81-122 in Goshal, V., Stennek, J. (Eds) The Political Economy of Antitrust, Elsevier: North Holland.

Cohen, M. A. and D. T. Scheffman (1989) "The Antitrust Sentencing Guideline: Is the Punishment Worth the Costs?” Journal of Criminal Law, 27, pp. 331-366.

Combe, E. and C. Monnier (2010) "Fines against hard-core cartels in Europe: the myth of overenforcement", forthcoming Antitrust Bulletin.

Connor, J.(2006) "The Great Global Vitamins Conspiracy, 1989-1999", second edition of Global Price Fixing, Heidelberg: Springer Verlag.

Connor, J. (2007) "Price-Fixing Overcharges: Legal and Economic Evidence", Chapter 4, pp. 59-153 in John B.Kirkwood (editor), Volume 22 of Research in Law and Economics, Elsevier.

Connor, J. (2010), Price-fixing overcharges, 2nd Edition. (First edition available online at http://papers.ssrn.com/sol3/papers.cfm?abstract_id=787924)

Connor, J. (2011), "Has the European Commission become more severe in punishing cartels? Effects of the 2006 Guidelines," European Commission Law Review, forthcoming. 
Connor, J. M. and Y. Bolotova (2006). A Meta-Analysis of Cartel Overcharges. International Journal of Industrial Organization 24, pp.1109-1137

Connor, J. and R. Lande (2006), "The Size of Cartel Overcharges: Implications for U.S. and EU Fining Policies”, Antitrust Bulletin 51, pp. 983-1022.

D'Aspremont, C. and M. Motta (2000), "Tougher price competition or lower concentration: a trade-off for anti-trust authorities?", in Norman, G. and J.-F. Thisse, Market Structure and Competition Policy, Game Theoretic Approaches, Cambridge University Press.

Demange, G. and J.P. Ponssard (1985), "Asymmetries in cost structures and incentives towards price competition" International Journal of Industrial Organization, 3, pp. 85-100.

Erickson, R., and A. Pakes (1995): "Markov-Perfect Industry Dynamics: A Framework for Empirical Work", Review of Economic Studies, 62(1), pp. 53-82.

Folz, M., Raysseguier, C. and A. Schaub (2010), Rapport sur l'appréciation de la sanction en matière de pratiques anticoncurrentielles, 2010.

Friedman (1971), “A non-cooperative equilibrium for supergames”, Review of Economic Studies, 38, pp.1-12.

Fudenberg, D. and E. Maskin (1986), "The Folk Theorem for repeated Game with Discounting and Incomplete Information” Econometrica, 54 (3), pp. 533-554.

Gallo J. (1994), "Criminal penalties under the Sherman Act: A study in law and economics", Research in Law and Economics, 16, pp. 25-71.

Garoupa, N. (2001) “The optimal magnitude and probability of fines", European Economic Review, 45, pp. $1765-1771$.

Ginsburg, D.H. and J.D. Wright (2010) “Antitrust Sanctions”, Competition Policy International 6(2), 339 ,

Gromb, D., J.-P. Ponssard and D. Sevy (1997) "Selection in Dynamic Entry Games", Games and Economic Behavior, 21, pp. 62-84.

Harrington, J. (2004) "Cartel pricing dynamics in the presence of an antitrust authority", RAND Journal of Economics, 35 (4), pp. 651-673.

Harrington (2010) "Comments on Antitrust Sanctions", Competition Policy International 6(2), 41-51,

Hinloopen, J. (2006) "Internal cartel stability with time-dependent detection probability", International Journal of Industrial Organization, 24, pp. 1213-1229.

Ivaldi, M., B. Jullien, P. Rey, Paul Seabright and Jean Tirole. (2003) "The Economics of Tacit Collusion." Final Report for DG Competition, European Commission, IDEI Toulouse.

Landes, W.H. (1983), “Optimal Sanctions for Antitrust Violations”, University of Chicago Law Review $50,652-678$.

Maskin, E. and J. Tirole (1988) "A Theory of Dynamic Oligopoly, II: Price Competition, Kinked Demand Curves, and Edgeworth Cycles”, Econometrica, 56 (3), pp. 571-599.

Motta, M. (2004), Competition Policy Theory and Practice, Cambridge University Press.

Motta, M. and M. Polo (2003) "Leniency programs and cartel prosecution", International Journal of Industrial Organization, 21, pp. 347-379. 
OXERA (2009) "Quantifying antitrust damages, towards non-binding guidance for courts", Study prepared for the European Commission.

Phlips, L. (1995), Competition Policy: a Game Theoretic Perspective, Cambridge University Press.

Ponssard, J.P. (1991) "Forward induction and sunk costs give average cost pricing", Games and Economic Behavior, 3, 221-236.

Rothschild, R. (1999) "Cartel stability when costs are heterogeneous" International Journal of Industrial Organization, 17, pp. 717-734.

Shubik, M. (1980), Market Structure and Behavior, Harvard University Press, Cambridge Mass.

Souam, S. (2001) "Optimal antitrust policy under different regimes of fines" International Journal of Industrial Organization, 19 (1), pp. 1-26.

Sutton, J. (1991), Sunk Costs and Market Structure. MIT Press. Cambridge, MA.

Tirole, J. (1988), The Theory of Industrial Organization, MIT Press.

Veljanovski, C. (2010) "European Commission Cartel Prosecutions and Fines, 1998-2006 - An Updated Statistical Analysis of Fines Under the 1998 Penalty Guidelines", Available at SSRN: http://ssrn.com/abstract $=1016014$

Verboven, F. (1997) "Collusive behavior with heterogeneous firms" Journal of Economic Behavior \& Organization, 33, pp. 121-136.Werden, G. and M. Simon (1987), "Why price fixers should go to prison?", The Antitrust Bulletin, pp. 917-137.

Wils, P.J. W (2006), “Optimal Antitrust Fines: Theory and Practice”, World Competition 29(2):183208. 